\title{
Bonding, firm value and liquidity: An analysis of migrations between the AIM and the Official List of the London Stock Exchange
}

\author{
Kevin Campbell and Isaac T. Tabner* \\ Saturday, 12 January 2013
}

\begin{abstract}
Firms that change their listing from the less regulated AIM to the more regulated main section of the London Stock Exchange exhibit positive abnormal returns on the announcement day. For firms moving in the opposite direction, both announcement and implementation day abnormal returns are negative. Following implementation, the pattern is reversed for both categories of firm. We show that differences in liquidity and in medium to long term firm survival rates between the two listing regimes do not explain the observed patterns of abnormal returns, suggesting that the answer lies in the different bonding requirements of the two market segments.
\end{abstract}

Keywords: Corporate Governance, Listing Change, Agency Costs, Agency Risk, Bonding Costs, Alternative Investment Market (AIM).

EFM Codes: 110, 150, 210, 230.

Contact details: Both Isaac Tabner and Kevin Campbell are at the Accounting and Finance Division, Stirling Management School, University of Stirling, Scotland, UK, FK9 4LA. Phone: 44 (0) 1786 - 467305, Fax: 44 (0) 1786 - 467308, E-mail: isaac.tabner@ stir.ac.uk and: kevin.campbell@stir.ac.uk.

\section{Acknowledgements:}

The authors would like to thank the University of Stirling for funding this research; Leone McKinley for providing invaluable research assistance; the participants of the 2008 Scottish area conference of the British Accounting Association (11 ${ }^{\text {th }}$ September 2008); participants of the University of Stirling Accounting and Finance Seminar $\left(19^{\text {th }}\right.$ November 2008); participants of the 7 th International Conference on Corporate Governance: "Corporate Governance: Managing Risk in a Changing World", Birmingham Business School Monday, 29th June 2009, including Erik Theissen and Bastian Hinterramskogler for their valuable comments; participants at the $8^{\text {th }}$ National Taiwan University International Economics, Finance and Accounting Conference, $23^{\text {rd }}$ June 2010, including Wan-Jiun Paul Chiou and Hao-Chen Liu. Any remaining errors are the responsibility of the authors.

*Corresponding author. 


\section{Introduction}

We examine the value relevance of bonding obligations and agency risk in firms listed on the London Stock Exchange (LSE) by studying the stock price and liquidity reactions to the announcement and implementation of migrations between two sections of the LSE; namely, the Alternative Investment Market (AIM) and the Official List (main section). These transactions are economically significant. The total value of firms moving up to the Official List over the study period from January 1996 through February 2011 was $£ 22.3 \mathrm{bn}$ while the corresponding figure for firms moving down to the AIM was $£ 4.8 \mathrm{bn}$. After controlling for firm size, style, industry and liquidity, we find that firms graduating from the AIM to the main section of the LSE generate positive abnormal returns on the day the decision is announced. For firms moving in the opposite direction, corresponding abnormal returns are negative. After the listing change is implemented, the pattern is reversed for both categories of firm so that firms moving up earn lower abnormal returns while firms moving down earn higher abnormal returns. We also observe substantial changes in three measures of liquidity in the period prior to, during and following implementation of a listing switch. However, these liquidity changes are transitory and we find no discernible difference between liquidity levels one year prior to and one year after the listing change.

Our study makes five contributions to the literature. First, we draw attention to the role of agency risk in explaining the differential returns of firms in the two listing regimes. Second, we use daily returns as opposed to the weekly returns typically used in other studies, and a benchmark returns model that controls for industry residual returns and the possibility of an interaction between market risk and change of listing status. Third we control for three measures of liquidity: the bid ask spread, standardised trading volume and the free float. Unlike other studies that compare migrations between market segments (for example, Baker and Edelman 1992a; Baker and Edelman 1992b; Bacmann, Dubois and Ertur 2002; Clyde, 
Schultz and Zaman 1997; Carvalho and Pennacchi 2012; Lamba and Arif 1997; Lamba and Khan 1999; Tse and Devos 2004; Leitterstorf, Nicoletti and Winkler 2008, Gerakos, Lang and Maffett 2011; Jenkinson and Ramadorai 2012; Vismara, Paleari and Ritter 2012) we find substantial changes in liquidity that are transitory ${ }^{1}$. Similar changes are not reported by these studies because they search for permanent rather than transitory changes in liquidity. Fourth, we empirically examine changes in risk and return resulting from changes in listing status. Fifth, complementing Espenlaub, Khurshed and Mohamed (2012) we find that while short term survival rates are somewhat higher for firms seeking promotion, the medium to long term survival rates are identical for both categories of firm. This suggests that differences in bankruptcy risk do not drive the observed return patterns, implying that differences in agency risk are responsible.

Determining the level of corporate governance regulation that balances the costs of disclosure and compliance requirements with the benefits of a stock exchange listing is an important and challenging problem. The "bonding hypothesis" proposed by Coffee (1999) and Stulz (1999) suggests that firms can bond themselves to good corporate governance by listing on a foreign stock exchange with higher governance standards and thus constrain insiders from appropriating wealth from minority shareholders. Likewise, Skaife, Collins and LaFond (2004) demonstrate that a firm's corporate governance attributes influence both its systematic and non-systematic risk and, hence, its cost of capital, implying the existence of "agency risk" as an asset pricing variable.

Firm managers may mitigate agency risk by committing the firm to greater bonding, thus signalling to investors that agency costs will be easier to control. One way of doing this is to seek a listing on an exchange that requires greater bonding commitments: either by a cross listing, or by migration. Motivations for cross listing, such as the effect of a firm's

\footnotetext{
${ }^{1}$ While Lamba and Arif (1997) and Clyde, Schultz and Zaman (1997) do examin cumulative abnormal trading volume for listing promotions on the Japanese and US stock markets respectively, they only consider unidirectional switches.
} 
country of origin on corporate governance standards and firm valuation, have been examined in a number of studies (e.g. Hail and Leuz, 2009; Lel and Miller, 2008; Doige, Karolyi, and Stulz 2007; Pagano, Roell and Zechner, 2002; La Porta, Lopez-De-Silanes and Shleifer, 1999; Foerster and Karolyi, 1999; Amira and Muzere, 2011). The primary focus of these studies is firms that list on, or migrate to, a more regulated exchange, rather than on firms that migrate from a more to a less regulated exchange.

The present study falls into a second category of studies that examine migrations between different regulatory and governance regimes within the same geographic or legal jurisdiction and with a common stock exchange trading technology. Such studies that focus on firms transferring between different tiers of the same market have the advantage of controlling for the legal protection afforded to shareholders. In our case, this is identical for the two segments of the London Stock Exchange. Within-country studies also reveal the ability of individual stock exchanges to influence the level of investor protection over and above that provided by existing law.

Our results have important economic implications. The tradeoff between agency risk and bonding costs is relevant to firm managers when determining an appropriate listing venue; investors weighing up the implications of an investee firm's listing choice; and regulators determining appropriate mechanisms of regulatory oversight. Our results indicate that this trade-off determines the switching decision. They also demonstrate the importance of controlling for time series variations in liquidity in return generating models to remove potential omitted variable bias. Likewise, our decomposition of liquidity into transitory and permanent components enhances the strength of our results.

The rest of the paper is organized as follows. In section 2, we consider the UK institutional context with respect to the LSE and AIM. The theoretical background and hypotheses are detailed in section 3 , followed by a discussion of the data characteristics in section 4 . The results and conclusions are presented in sections 5 and 6 respectively. 


\section{The London Stock Exchange and AIM}

Taken together the two sections of the LSE have characteristics which make them particularly suited to a study of the influence of the regulatory environment on the cost of capital. For example, although the main market of the LSE ranks highly in terms of the level of investor protection provided (La Porta, Lopez-De-Silanes, Shleifer, and Vishny, 1997; La Porta, Lopez-De-Silanes, Shleifer, and Vishny, 1998; La Porta, Lopez-De-Silanes, and Shleifer, 1999; Bebchuk, 2005; Bebchuk, 2007; Becht, Franks, and Rossi, 2009) the AIM section of the LSE is, arguably, one of the most lightly regulated markets in the developed World. Additionally, more than twice as many firms transfer from the main market to the AIM as transfer in the other direction. It is unusual to see such a high number of firms seeking to migrate from a more regulated exchange to a less regulated exchange within the same jurisdiction. In fact, on many junior exchanges, it is either not possible for them to accept firms from their more senior counterparts, or else such an occurrence is considered exceptional. Firms listed on most multi-tier exchanges typically seek promotion to a more senior exchange, or, if delisting, seek a complete removal of their quotation.

The less stringent corporate governance, financial reporting and listing requirements imposed on AIM firms, compared to firms on the main market, is a characteristic that, arguably, results in a higher cost of capital. Firms listed on the main market are subject to the "comply or explain" principle of the UK Corporate Governance Code, formerly known as the Combined Code (Financial Reporting Council, 2010). Although the efficacy of the “comply or explain" principle may be questioned (e.g. MacNeil and Li, 2006) AIM firms do not have to abide by it; instead they only have to apply the AIM Rules for Companies (London Stock Exchange, 2010). These contain provisions concerning the conduct of directors and the disclosure of remuneration and other information that are significantly less onerous than the UK Corporate Governance Code. Following the Enron scandal and the passage of the Sarbanes Oxley Act (SOX) in 2002, the cost of listing in the US increased 
relative to the London markets (among others) making London markets potentially more attractive locations for foreign firms. In fact, Piotroski and Srinivasan (2008) find that large foreign firms are no less likely to choose the US market over London, but smaller firms are more likely to consider a UK listing, and in particular an AIM listing over a US listing, post SOX. This suggests that for smaller firms, the lower cost of maintaining a listing on AIM potentially outweighs the higher cost of capital, including higher agency costs.

There is considerable overlap in size between firms listed on the AIM and on the main market. For example, after excluding investment firms and firms with a market capitalization of less than $£ 1 \mathrm{~m}$, on 31 March 2011 there were 574 UK firms with ordinary shares listed on the main market: of these, $421(73 \%)$ had a market capitalization less than the $£ 1.39$ bn market capitalization of the largest firm listed on the AIM (London Stock Exchange 2011a). With no prescribed governance requirements in the AIM Rules for Companies, AIM companies will often look to the main market's UK Corporate Governance Code for guidance on key aspects of governance. However, Snell and O’Brien (2008) find that whilst $77 \%$ of the Top 100 AIM companies by size comply with some aspects of this Code, only 3\% choose to fully adopt it. Many firms listed on the AIM have concentrated shareholdings because, unlike the Main Market which specifies $25 \%$ as the minimum free float, there is no such requirement for AIM firms. Furthermore, many AIM firms have never made a profit and can be characterized as pure plays on a particular technology or business plan. As a result, they tend to be riskier than firms listed on the main market, which generally have a longer trading history, a more demonstrable record of profitability and a higher free float. When AIM firms are able to demonstrate a sustainable record of profitability and a market capitalization exceeding $£ 500 \mathrm{~m}$ they are encouraged by the LSE to transfer their listing to the main market, but this is not obligatory (Arcot, Black, and Owen, 2007, p. 39). In fact, we find that more than twice as many firms move from the main market to the AIM than move in the opposite direction, while the overlap in size 
between firms on both exchanges suggests that many firms choose not to seek promotion, even if they meet the criteria.

Nominated advisors (also known as nomads) are a specific feature of the AIM Market and their retention by AIM firms is mandatory. Generally investment banks, accountancy firms or corporate finance advisory firms, they are approved by the LSE and are responsible for assessing the appropriateness of an applicant for AIM and for contacting the AIM regulation team when they believe that a firm for which they act is no longer appropriate for AIM (AIM Nomad Rule 14). Although some firms on the main market may be tempted to move to the AIM to take advantage of its less prescriptive regime ("regulatory arbitrage") the LSE and the Financial Services Authority expect both nomads and institutional investors to ensure that companies raise their corporate governance standards as they increase in size (Arcot, Black and Owen, 2007, p. 23). However, investigations of corporate governance disclosure among AIM firms have uncovered a variety of corporate governance practices, with larger AIM companies not necessarily providing better governance (Mallin and Ow-Yong, 1998, 2008; Snell and O’Brien, 2008). Notwithstanding the AIM rules and the UK Listing Authority (UKLA) rules, our findings indicate that firms often provide very little notice or justification for a listing change and shareholders are often not given the opportunity to vote for, or against, the change.

In their comparison of the AIM with the NASDAQ and OTC Bulletin Board (OTCBB) in the US and the LSE Main Market in the UK, covering the period June 27th 1995 to December 31st 2008, Gerakos, Lang and Maffett (2012) find that AIM firms produce lower returns, have lower liquidity and are significantly more likely to fail. The authors highlight the AIM's more relaxed regulatory environment and characterise it as "much more like a landing pad for struggling firms than a launching pad for highfliers" (p. 24). In particular, they draw attention to the delegation by the LSE of responsibility for establishing the appropriate level of oversight to nomads, pointing out that these are private sector organisations hired and paid for by AIM firms. The regulatory environment in which 
AIM firms operate thus poses greater agency risks for investors, so firms that use the AIM as a launching pad for the LSE are willing to incur greater regulatory costs to bond themselves to investors when they migrate upwards, while those LSE firms using the AIM as a landing pad are trading off greater agency costs against the reduced burden of regulation and disclosure when they migrate downwards.

The possibility that the lower standard of regulation on the AIM attracts lower quality firms that are unable to list in more regulated markets was investigated by Nielsson (2012). His results show that firms listed on AIM, although smaller in size, are equivalent in terms of profitability, growth and leverage to firms listed in the NYSE and NASDAQ exchanges in the U.S. and in two Continental European exchanges (the Deutsche Börse and Euronext). He also demonstrates that the delisting pattern is the same across these markets and concludes that the AIM does not cater to lower quality firms.

As well as sending signals about future agency costs and firm performance, a decision to transfer a listing may have important tax consequences for UK residents investing in main market and AIM firms. This is because, unlike firms listed on the AIM, firms on the main market are eligible for inclusion in an Individual Savings Accounts (ISA). An ISA is a tax shelter enabling private investors to avoid capital gains tax and to receive limited reductions in dividend income tax. Although not eligible for inclusion within an ISA, investors in AIM firms enjoyed other generous tax incentives during the study period that were not available to investors in main market firms, including: entrepreneurs' relief against capital gains tax, enterprise investment scheme tax relief and inheritance tax business property relief. Hence, firms that switch their listing without providing adequate warning may trigger forced sales by investors and unforeseen tax liabilities.

\section{Theoretical background and research hypotheses}

Firms may change their listing, or list on more than one exchange, when the group of investors with the greatest comparative advantage in assessing their value are based on a 
foreign exchange (the "investor recognition hypothesis" of Merton (1987)). Alternatively, a listing change may occur when a foreign exchange has a higher listing standard, thus allowing the firm to signal to potential investors that it is prepared to subject itself to higher standards of disclosure and corporate governance, thereby justifying a lower cost of capital (the "bonding hypothesis", e.g. Coffee (1999)). A further possibility is that firms may change their listing when analyst coverage and the pool of potential investors is larger on another (usually foreign) exchange, resulting in greater liquidity and lower transaction costs (respectively, the "liquidity hypothesis" of Amihud and Mendelson (1986) and the "market segmentation" hypothesis of Kadlec and McConnell (1994)).

Competing exchanges can either "race to the top" or "race to the bottom" when setting their listing requirements. Indeed regulatory arbitrage can work both ways as firms may "race to the top" in seeking listings on exchanges with more stringent corporate governance standards than found in their home country (Coffee 1999; Piotroski and Srinavasan 2008 and Pagano et al. 2002). In fact, Chemmanur and Fulghieri (2006, p. 458) argue that "high reputation" exchanges are likely to reinforce their comparative advantage by setting high listing standards, while "low reputation" exchanges will set lower standards and become lower-tier markets.

It is also probable that firms with concentrated ownership are inclined to avoid listing on exchanges where greater rights are afforded to minority shareholders Coffee (1999, p. 703). According to this reasoning the AIM is likely to be favoured over the main market by firms with concentrated ownership not least due to the absence of free float restrictions on AIM firms.

The decision to alter listing status may also be influenced by the additional financial disclosures required on a more regulated exchange as these serve to bond a firm's managers to its shareholders and thus reduce agency risk. However, smaller firms may have less wish to incur additional bonding costs. Likewise firms with controlling shareholders may not regard an increase in bonding costs to be worth the resulting reduction in agency risk. If 
increased bonding costs incurred by firms graduating to the main market are outweighed by a lower cost of capital, asset pricing theory suggests that their stock prices should rise and subsequent expected returns should fall on the announcement of such a switch. This is because the risk premium declines to reflect the lower agency costs of an official listing. This leads to our first hypothesis:

Hypothesis 1. Firm value will increase immediately following the announcement and transfer of firms from the AIM to the main market, followed by subsequent lower returns.

On the other hand, firms transferring down from the main market to the AIM might be expected to initially suffer a stock price fall, but eventually the additional risk premium required to compensate for the higher agency costs of the less regulated market should result in higher returns, in equilibrium. This reasoning generates our second hypothesis:

Hypothesis 2. Firm value will decrease immediately following the announcement and transfer of firms from the main market to the AIM, followed by subsequent higher returns.

In a study of firms seeking promotion from the American Stock Exchange (AMEX) to the New York Stock Exchange (NYSE), Baker and Edelman (1992a) observe a pre migration rise in firm values and a post migration fall. They also observe that the premigration rise is greatest for firms whose stocks exhibit low stock trading volume. Similar results with respect to upward migrations on the Tokyo Stock Exchange (TSE) are found by Lamba and Arif (1997). If the motivation for seeking promotion to the main market is to raise the value of the firm's equity for the benefit of existing investors and to make it easier for firms to raise capital to exploit additional investment opportunities, it is useful to consider the theory on seasoned equity offerings (SEOs) and initial public offerings (IPOs). Rational wealth maximizing investors will not be persuaded to provide additional equity to a firm through either of these two methods unless the managers demonstrate the existence of positive net present value (NPV) investment opportunities. 
Empirical literature and theory on SEOs and IPOs suggest that this will be easier to achieve if recent operating and investment returns have been good (for example, Brau and Fawcett 2006). However, there is also evidence that good performance is often not sustained post fund raising (e.g. DeAngelo, DeAngelo, and Stulz, 2010; Brau and Fawcett, 2006). Given the analogy between firms seeking promotion from the AIM market to the main market and capital raising through IPOs or SEOs, it is conceivable that pre-implementation and postimplementation performance may be inversely related. A firm's promotion to the main market may also justify higher salaries for the executives and facilitate the sale of founders' shareholdings. Therefore, it is also possible that managers of AIM firms time their exit onto the main market to coincide with the end of a period of good performance in order to maximize personal benefits, perhaps exploiting information asymmetry between themselves and outside investors. Another possibility is that they may be tempted to actively groom a firm's accounts via earnings management and other techniques in order to facilitate this process, as has been documented prior to IPOs and SEOs (Lee and Masulis, 2009; Lee and Masulis, 2011). This leads us to our third hypothesis:

Hypothesis 3. The pre-implementation abnormal returns of firms transferring from the AIM to the main market are inversely related to post-implementation abnormal returns.

Transferring from the main market to the AIM can be viewed as a preliminary step towards delisting, analogous in some respects to the SEC de-registration processes examined by Leuz, Triantis, and Wang (2008). Transfers to AIM are likely to result in the concentration of power among block holders and firm managers at the expense of outside minority shareholders. In fact some of the firms in our sample explain the motivation for their decision to transfer to AIM by stating that additional funds provided by a major investor will reduce the free float below the $25 \%$ minimum required on the main market. For example, API Group PLC, which transferred to AIM on $12^{\text {th }}$ February 2008, stated in an announcement on the $17^{\text {th }}$ December 2007: 
"As a result of the Open Offer launched on 17 December 2007 and approved at the General Meeting, the Company no longer expects to be in compliance with the Listing Rule requiring at least 25 per cent of its shares to be in public hands, once the new shares are admitted on the 18 January 2008. In assessing the options, the Directors have concluded that AIM, with its more flexible regulatory environment, may in any case provide a more appropriate market for the Company's shares."

Reduced regulation, lighter reporting requirements and greater concentration of executive power are arguably more conducive to corporate restructuring than a regime favouring dispersed minority shareholders such as the main market. Hence, firms transferring from the main market to the AIM are likely to have underperformed relative to the market as a whole.

It could be argued that the more extreme the underperformance the greater the scope to realise value through restructuring. However, there is also likely to be greater uncertainty regarding the ongoing viability of the firm or the likelihood of the restructuring being successful. In fact, when firms transfer to the AIM market it is not clear to investors ex-ante whether the action is taken for the purpose of maximising shareholder value or for the purpose of entrenching incompetent management. Given the reduction in disclosure and bonding requirements resulting from a transfer to AIM, the information asymmetry between inside investors/managers and outside investors/minorities, announcement and implementation of the decision may also signal to investors that the firm's underperformance is more severe than previously disclosed. As uncertainty increases prior to and during the listing change, firm valuations are likely to fall in response to the increasing cost of capital and declining business performance. The subsequently devalued firms that survive and benefit from restructuring will, on average, generate higher total returns from the devalued asset base reflecting the greater cost of capital required by investors as a risk premium for bearing the uncertainty. This leads us to our fourth hypothesis: 
Hypothesis 4. The pre-implementation abnormal returns of firms transferring from the main market to the AIM are inversely related to post-implementation abnormal returns.

In a study of delistings from the AMEX to the NASDAQ, Clyde et al. (1997) find that post migration bid-ask spreads are double premigration levels but that returns are also higher post migration. This finding is also reported by Tse and Davos (2004) who examine migrations in the opposite direction, i.e. to the AMEX from the NASDAQ, finding that firms migrating to the AMEX from the NASDAQ are larger than firms migrating in the opposite direction. Likewise, post migration spreads are narrower and post migration returns are lower for firms switching to the AMEX. Their results are consistent with the investor recognition hypothesis of Kadlec and McConnell (1994). The higher listing standards on more regulated exchanges, such as the main market, provide a signal of quality which enhances liquidity by attracting investors (Macey and O'Hara 2002; Harris 2006). The absence of free float restrictions together with less stringent listing and reporting requirements that apply to firms listed on the AIM may result in AIM firms exhibiting greater information asymmetry between insiders and minority shareholders than firms listed on the main market. Following work by Glosten and Milgrom (1985) there is substantial theoretical and empirical evidence that market makers increase the bid-ask spread as a protection mechanism in the face of perceived information asymmetry.

There is evidence that investors discount the value of infrequently traded securities (Easley and O'Hara 2010) and the value of shares with a low expected liquidity (Ellul and Pagano 2006). This supports the theory that liquidity is an important source of priced risk and implies that reductions in liquidity lead to reductions in firm value (Liu 2006; Litvak 2009). Arguments asserting that liquidity affects firm value by changing the discount rate are classified by Fang, Noe and Tice (2009) as pricing-based theories. In their empirical study of US stocks in the period from 1993 to 2004 they find that liquidity improves firm performance, as measured by the Tobin's Q ratio, and attribute their result to two 
mechanisms: the stimulation of the entry of informed investors who make prices more informative to stakeholders and an increase in the efficiency of performance-sensitive managerial compensation.

Changes in liquidity that occur around an exchange listing may be a manifestation of the price pressure hypothesis of Scholes (1972) and Kraus and Stoll (1972) which asserts that short-term demand curves may be less than perfectly elastic such that a sudden demand shock stimulates an immediate price reaction that subsequently dissipates to compensate those providing liquidity. Such a possibility is investigated by Chuang, Liao and Yu (2009) in their examination of migrations of firms from the junior OTC market in Taiwan to the Taiwan Stock Exchange (TSE) over the period from January 1992 through December 2006. Both markets are structurally similar, employing the same order-driven auction system. They find that migrating stocks' liquidity improves substantially following the announcement, peaks around the listing day and then diminishes after listing such that there is no significant change over the twelve-month period following the listing. They also find an increase in abnormal returns before the listing which are partially reversed following the listing. They conclude that these price and liquidity patterns are consistent with the price pressure hypothesis and reflect portfolio rebalancing by investors triggered by the exchange migrations. If listing switches result in an increase in the information asymmetry between informed traders and uninformed traders market makers will increase the bid-ask spread (Glosten and Milgrom, 1985). Normally it might be expected that decreases in bid-ask spreads and increases in trading volume are associated with improvements in liquidity. However, Kim and Verrecchia (1994) propose a model in which trading volume increases concurrently with increases in bid-ask spreads and decreases in liquidity in situations where the increase in bid-ask spread is insufficient to eliminate the profit opportunities available to informed traders as they exploit their information advantage. The impact of the differences in liquidity between the Canadian and US stock markets is examined by Carpentier, Cumming and Suret (2011) over the 1993 to 2007 period. Given the weaker initial listing 
requirements in Canada relative to the US, they examine relative IPO valuations and find significantly lower Canadian IPO valuations, consistent with the weaker Canadian regulations. However, this valuation differential disappears for IPOs with similar liquidity, leading the authors to conclude that the liquidity gap between the two markets, rather than the difference in initial listing standards, is the main factor behind the valuation differential.

The preceding arguments lead us to propose our fifth and sixth hypotheses, based on the argument that announcements of transfers between listing regimes may be perceived as a signal of future liquidity and thus affect transaction costs. Investors in firms switching from the AIM to the Main Market would anticipate positive abnormal returns due to the reduced cost of trading their shares in the future. Conversely, firms switching from the Main Market to the AIM would anticipate their prices to be marked down by investors because of reduced liquidity.

Hypothesis 5: Firms switching from the AIM to the Main Market experience an increase in liquidity.

Hypothesis 6: Firms switching from the Main Market to the AIM experience a decrease in liquidity.

\section{Characteristics of the data}

Firm names, announcement dates and implementation dates of listing changes were obtained from the London Stock Exchange "New Issues and IPO Summary" spreadsheet (London Stock Exchange 2011b) and the NexisUK database of aggregated regulatory news from the London Stock Exchange. Close to close trading day periods are used to measure total daily shareholder, industry sector, market and risk free returns. Therefore, in all subsequent discussions trading days are referred to simply as days and daily returns are the returns achieved over a close to close period. For all firms, daily excess returns over the 
contemporaneous risk free rate of interest were calculated by geometric differencing. ${ }^{2}$ Market excess returns are proxied by the capitalization weighted average excess returns of the FTSE AIM All Share Index and the FTSE All Share Index returns. Additional control variables include the small firm premium (SMB) calculated by taking the geometric difference of the FTSE Small Cap Index and the FTSE 100 Index daily total returns; the value premium (VMG) calculated as the geometric difference between the FTSE Value Style Index and the FTSE Growth Style Index; daily trading volume for each firm in the sample; the daily closing bid-ask spread for each firm in the sample; the number of shares outstanding and finally the percentage free float for each firm in the sample from the $19^{\text {th }}$ April 2002 when it first became available on Thomson Reuters Datastream.

Firms were sorted into two groups, those transferring from the AIM to the main market (AIM2MAIN) and those transferring from the main market to the AIM (MAIN2AIM). Our sample period began in January 1996 and ended in December 2010, although there were no switches until 1997.

Figure 1 shows that the number of AIM2MAIN firms peaked in 1998 and subsequently declined to a trough of just 2 firms in 2005 before increasing again in 2007 and 2008. The number of MAIN2AIM firms moving in the opposite direction peaked in 2003 before declining in 2009 to the lowest level since 1996. Between 2000 and 2006 the number of MAIN2AIM migrations exceeded the number of AIM2MAIN migrations, a pattern reversed with the onset of the financial crisis in 2007. The number of firms moving in each direction does not correspond with general fluctuations in the stock market. The peak of MAIN2AIM migrations occurred in 2003 when the market reached a low point, and the number of AIM2MAIN migrations subsequently increased relative to MAIN2AIM during the onset of the financial crisis in 2007 and remained higher through 2010, the final year of the study.

\footnotetext{
${ }^{2}$ UK Treasury Bill Tender 3 Month Yield Middle Rate, (DataStream Code UKTBTND).
} 


\subsection{AIM2MAIN firms}

After excluding foreign firms, firms with missing data and firms with non UK ISIN numbers, we are left with a sample of 111 firms which migrated from the AIM to main market.

The reasons given by firms in their announcements for transferring their listing are summarized in table 1 . The statements of $42 \%$ of the AIM2MAIN firms do not contain any justification of the re-listing decision. The migrations of 40 of the remaining firms coincides with a positive growth forecast or statement that the main market is now appropriate given the firms size, 39 believe it will raise their profile, 36 believe a move to the main market will increase their shareholder base, and 30 explicitly state an expected improvement in liquidity among their motivations. Other reasons given include better regulation, better potential to enact mergers and acquisitions, better analyst coverage and a greater ability to attract talented personnel.

Insert Table 1 about here

In table 2, it is reported that the majority of AIM2MAIN firms are from the DataStream consumer services sector (24) followed closely by financials (31), industrials (18), technology (14) and healthcare (11). The remaining five sectors - oil and gas, telecoms, utilities, basic materials and consumer goods - comprise a total of just 13 firms. Of the 111 firms in the sample, the median number of trading days between the announcement of a listing change and its enactment (implementation lag) is 39, the 
maximum is 607 and the minimum is 0 (one firm only: Staffware. ${ }^{3}$ The median market capitalization on the implementation day is $£ 122.5 \mathrm{~m}$ and the maximum is $£ 1.1 \mathrm{bn}$.

Insert Table 2 about here

\subsection{MAIN2AIM firms}

After excluding foreign firms, firms with missing data and firms with non UK ISIN numbers, we are left with a sample of 262 firms which migrated from the main to the AIM section, including MDY Healthcare which is entered twice because it moved from the main market to the AIM, back to the main market and then back to the AIM a second time.

From table 1 , it is evident that $16 \%$ of MAIN2AIM firms, compared to $42 \%$ of AIM2MAIN firms, do not feel the need to justify their move to shareholders. Half of the firms state that the migration will facilitate the growth of the firm and that the new market is more appropriate for the firm's size. More favourable regulation is also frequently cited as a motivation for the $48 \%$ of the MAIN2AIM group. General flexibility regarding corporate transactions is mentioned in $40 \%$ of the statements justifying migration, while about $11 \%$ mention some form of restructuring process.

Examination of table 2 reveals that the median implementation lag is 23 days which is quicker than the 39 day median observed in the AIM2MAIN sample. Two firms moved just ten days from the announcement day. ${ }^{4} \mathrm{~A}$ short implementation lag has potentially

\footnotetext{
${ }^{3}$ Under AIM Rule 41 “An AIM company which wishes the Exchange to cancel admission of its AIM securities must notify the Exchange of its preferred cancellation date at least twenty business days prior to such date and save where the Exchange otherwise agrees, the cancellation shall be conditional upon the consent of not less than $75 \%$ of votes cast by its shareholders given in a general meeting." However, in the case of firms moving from the AIM to the main market, firms can seek a waiver of rule 41 from the AIM regulation team of the London Stock Exchange. Waivers are considered on a case by case basis. This was confirmed by a telephone conversation by the author with a representative of the AIM regulation team on the $21^{\text {st }}$ of August 2008 .

${ }^{4}$ As applicable at August 2008, under UKLA rule 5.2.5 par. 2 a firm must obtain prior approval of a resolution for cancellation of not less than $75 \%$ of shareholders at a general meeting. Firms must also inform shareholders that the resolution for cancellation has been passed within 20 days following the date of the resolution and inform them of the intended date of cancellation. However, both UKLA rules 5.2.7 and 5.2.12 outline situations where rule 5.2.5 does not apply and firms are only required to provide advance notice of 20
} 
damaging consequences for investors who hold shares in an individual savings account (ISA), as AIM listed firms are not eligible to be held inside an ISA. ${ }^{5}$ It is also potentially damaging for private investors who may not be aware of the weaker shareholder protection mechanisms available on the AIM, particularly in situations where the requirement for a consultation period and shareholder approval for a delisting from the main market to the AIM is waived.

It is also evident from table 2 that the distribution of firms between sectors is somewhat different in the MAIN2AIM compared to the AIM2MAIN sample. The sector containing the most firms is industrials (79) followed by consumer services (44), consumer goods (41), technology (41) and financials (32). The remaining five sectors - basic materials, utilities, telecoms, oil and gas and healthcare - comprise 24 firms.

At $£ 9 m$ the implementation day median market capitalization is much lower for the MAIN2AIM firms than the $£ 123 \mathrm{~m}$ median observed for the AIM2MAIN firms. This is consistent with the assumptions underpinning hypothesis $3 \& 4$ to the effect that AIM2MAIN firms are likely to have exhibited recent growth and good performance while MAIN2AIM firms are likely to have exhibited poor performance and retrenchment.

\subsection{Survival record of switching firms}

A substantial proportion of both groups of firms ceased trading after their listing change, as summarized in table 3.

Insert Table 3 about here

\footnotetext{
business days before the intended cancellation of listing. In addition, a conversation between one of the authors and a member of the technical team at the UKLA on the $22^{\text {nd }}$ August 2008 indicated that in exceptional circumstances, the requirement of a minimum of 20 business days of notice may also be waived. Although Jenkinson and Ramadorai (2012) report that the rules were applied more rigorously from 2007 onwards and we find that from the beginning of 2007 the minimum implementation lag increased to 38 trading days and the median to 39 days.

${ }^{5}$ Individual Savings Accounts are tax shelters available as an annual allowance for individuals resident in the UK. For example, gains realised from eligible investments are free of capital gains tax.
} 
Of the 111 AIM2MAIN firms, a total of 52\% were classified by DataStream as no longer in existence by $4^{\text {th }}$ March 2011. Of all the AIM2MAIN firms, $41 \%$ survived for more than 5 years after migration and a clear majority survived for more than 3 years. The post implementation survival of the MAIN2AIM firms is similar to the AIM2MAIN counterparts as a total $52 \%$ of firms are classified as dead by the end of the study period. The rate at which MAIN2AIM firms die over the study period is similar to that of the AIM2MAIN sample and the majority of firms survive for 5 years or more, following migration.

\subsection{Choice of event date}

Standard event studies aim to capture the value of price sensitive information released on the event date which is reflected in the difference between the realized return and the expected return, based upon a return-generating model.

Many of the listing change announcements coincide with the release of other price sensitive information, such as annual results, interim results, fundraisings, trading statements and takeover bids. We hypothesize that promotions to the main market from AIM are likely to be associated with positive news, while transfers from the main market to the AIM are likely to be associated with unfavourable news, reflecting the possibility that a listing change may be a symptom rather than a cause of firm performance. Hence, we are able to make useful inferences about the overall health of firms making the respective announcements, both as reported on the announcement day and in the period leading up to the announcement by studying their price reaction on the announcement date.

We found little evidence of firms releasing additional price sensitive information on the implementation date, making this date 'clean' of confounding events. Implementation conveys the removal of the uncertainty, or execution risk. In the case of AIM2MAIN firms, it is also confirmation of the ability to meet the listing requirements of the main market. An event study based on the implementation date is also able to capture the effects of changes in liquidity arising as different categories of investors move into or out of a firm's stock 
around the migration date. For example, fully listed firms will be accessible to a wider clientele of investors, including private investors who are able to invest directly in main market firms through an ISA.

\section{Hypothesis testing and results}

\subsection{Zero - one model market adjusted returns}

For each group of firms, the daily geometric difference between firm returns and the market benchmark returns are calculated over a 501 day event period comprising 250 days before implementation of the listing switch and 250 days after, plus the implementation day. The cumulative (buy and hold) sample mean returns relative to the benchmark are then plotted in figure 2 for each of the two samples. For each sample, the two thick hashed lines indicate: (a) the market adjusted return that a hypothetical investor would have made by investing an equal amount of money into each firm 250 days before the implementation date, and then holding the position without rebalancing until 250 days after the implementation date and (b) the market adjusted return that the same investor could have made by initiating the strategy at the closing price on the implementation day. The thick black lines represent market adjusted returns in which the most extreme upper and lower $2.5 \%$ tails are excluded every day. The standard errors used to derive the $95 \%$ confidence bands are calculated using the whole (untrimmed) samples. Firms which die within the 250 day post implementation period contribute a return of minus $100 \%$ in the period leading up to death.

Examination of panel $\mathrm{A}$ of figure 2 shows that firm values in the AIM2MAIN sample increased by an average of around $40 \%$ relative to the market in the year prior to implementation and the lower $95 \%$ confidence band is above zero at the time of implementation. Average firm values subsequently decrease relative to the market by about $20 \%$ in the year following implementation. 
Panel B of figure 2 shows that, in contrast to the AIM2MAIN sample, the firms moving down to the AIM market decreased in value relative to the market by around $7 \%$ for the whole sample and $12 \%$ for the trimmed sample prior to the implementation day, although the upper $95 \%$ confidence band is still above zero at this point. Following implementation and until about 20 days afterwards, there is a further sharp fall in value relative to the market of around $13 \%$ for the whole sample and $17 \%$ for the trimmed sample. Following this, there is a recovery in values so that the average post-implementation market adjusted return to an investor who bought MAIN2AIM firms at the closing price on the implementation day and held them for one year is $5 \%$ for the untrimmed sample and zero for the trimmed sample.

Figure 2 demonstrates the return that a hypothetical buy and hold investor could have earned during the entire 501 day event window and over the 250 day post implementation period. The difference between the trimmed and untrimmed mean buy and hold returns plotted in figure 2 demonstrate that the accumulation of large returns from just a small number of firms can potentially cancel out the negative impact of many poorly performing firms. ${ }^{6}$

Insert Figure 2 about here

Figures 3 and 4 plot the compounded daily returns of an alternative hypothetical portfolio which is rebalanced to equal weights on a daily basis assuming zero transaction costs. This construction provides information about the ex-ante expected return path of an individual switching firm that will inform firm managers' decisions regarding listing choice

\footnotetext{
${ }^{6}$ During the Internet boom in 1999 - 2000, one firm, Izodia, increased in value by 3,079\% over the period day -250 to day -41 , but by the end of the event period it suffered a $48 \%$ decline from its starting value at day 250 , i.e. a $98 \%$ decline from its peak. This firm alone accounts for the considerable expansion in the $95 \%$ confidence bands around day - 50 in panel A of table 2. In fact, the increasing divergence between best and worst performing firm valuations during the 501 day event window explains the expansion in confidence intervals in the two panels of figure 2 .
} 
and provide investors with information about the expected risk and return of a portfolio containing switching firms' stocks.

Insert Figure 3 about here

Insert Figure 4 about here

The daily rebalancing to equal weights of the average returns exhibited in figures 3 $\& 4$ provide a robustness check confirming the general patterns displayed by figure 2 . The returns of the AIM2MAIN trimmed and untrimmed samples are presented in panels A and B, respectively, of figure 3 . Daily rebalancing reduces both the magnitude of the market adjusted returns and the width of the confidence intervals, while inclusion of the trimmed and untrimmed sample means further illustrates the importance of outliers in increasing market adjusted returns. A similar story is repeated in figure 4 for the MAIN2AIM sample where daily rebalancing and trimming makes the overall returns more negative preimplementation and less positive post implementation.

\subsection{Testing hypothesis 1 \& 2: event study model I}

Figures 2 to 4 plot the daily mean market adjusted returns of switching firms in the year before and after the switch. However, these patterns may fail to capture some of the special characteristics of switching firms. For example, it is evident from table 1 that a frequently cited motivation for a listing switch is to improve liquidity. Furthermore, switching firms are often small relative to the average size of firms listed on the LSE; they may be in high growth sectors; they may have higher or lower sensitivity to market risk than average; or they may have a higher or lower trading volume relative to similar firms. Therefore, least squared coefficients for model I are estimated for each firm, with individual 
excess returns used as the dependent variable. The independent variables of model I are identified in the left hand column of table 4. Time series data from 250 days prior to the announcement through to 250 days after the implementation date, the end of the study period, or the firm death date, whichever is first, are used to estimate the coefficients.

The specification of model I is designed to control for firm size and style, i.e. value minus growth, after Fama and French (1993); the possible influence of changes in liquidity during the pre and post event period on the return generating process (Liu 2006) ${ }^{7}$; and the possibility that return generating model parameters such as the intercept and market risk may differ before and after the implementation date (see for example, Baker and Edelman 1992a; Bacmann et al. 2002; Carlson, Fisher and Giammarino 2010). In addition to the inclusion of lagged firm returns as an independent variable, our model specification also includes coefficients on lagged market excess returns and lagged size and style factors to mitigate against thin-trading biases (Dimson, 1979). Both groups of firms, but especially firms in the MAIN2AIM sample, frequently experience days when no trading occurs. Therefore, we implement an additional mitigation for thin trading bias that, to the best of our knowledge, has not been implemented in prior research. Specifically, we substitute market excess returns for firm excess returns on days when both of the following two conditions are met simultaneously: (a) a firm's stock price does not change and (b) its trading volume is zero. These two conditions amount to missing data, because on zero volume days a return of zero does not necessarily reflect the return an investor could have made had they attempted to trade. Hence we refer to such days as 'no-price days' (NPDs). Our substitution is motivated by the principle that the least biased substitute for missing firm level data is likely to be the market excess return. We also encounter missing data related to free float and the bid-ask spread: for free float data we substitute $100 \%$ for the missing

\footnotetext{
${ }^{7}$ Our approach differs from that of Liu (2006) in that our model I includes contemporaneous and lagged changes in bid ask spread and scaled trading volume, whereas Liu constructs a liquidity risk factor from the return differential between portfolios of low and high liquidity stocks stocks defined according to his liquidity metric. Our method allows for greater time series variation in liquidity within firms.
} 
value, while for bid-ask spread data we substitute the mean bid-ask spread observed for that firm over the 501 day event period.

Insert Table 4 about here

The results in table 4 show that the intercept coefficients are not significant for either group of firms. However, the mean coefficients on the intercept dummy variables are negative for the AIM2MAIN sample and positive for the MAIN2AIM sample, while the test statistics are significant at the $\mathrm{p}<0.01$ and $\mathrm{p}<0.05$ levels respectively. This indicates that, on average, firms transferring to the main market subsequently underperform their peers, while firms transferring to the AIM market subsequently outperform their peers. In contrast, the announcement day returns are positive for the AIM2MAIN sample and negative for the MAIN2AIM sample, with significant test statistics at the $\mathrm{p}<0.05$ and $\mathrm{p}<0.01$ levels respectively. This indicates that the announcement of a firm's intention to move to the main market is associated with good news while the announcement of a transfer in the opposite direction is associated with bad news. These findings are consistent with hypotheses $1 \& 2$ and with the findings of Tse and Davos (2004) with respect to AMEX - NASDAQ - AMEX migrations. Implementation day returns are not significant for the AIM2MAIN sample, although they are significantly negative, at the $\mathrm{p}<0.05$ level, for the MAIN2AIM sample implying that either: (a) implementation conveys new information about firms switching down but not firms switching up, or (b) demand changes for firms switching down on implementation, but not for firms switching up. Examination of the control variable coefficients reported in table 4 shows that in the AIM2MAIN sample the positive interaction dummy variable coefficient testing for changes in firms' sensitivity to the market return factor post implementation is not significant, while for the MAIN2AIM sample the coefficient is negative and significant, at the $\mathrm{p}<0.05$ level, indicating that MAIN2AIM firms' sensitivities to market returns decline post implementation. This finding mirrors that 
of Bacman et al. (2002) who find increases in market risk for firms that migrate up to the senior segment of the French stock exchange. Both samples have coefficients on the market excess return variable that are positive and significant at the $p<0.01$ level. Likewise, both samples have coefficients on the small firm premium (SMB) that are positive and significant, at the $\mathrm{p}<0.01$ level. Conversely, sensitivity to the value firm style premium (VMG) is negative for both samples, although it is only significant in the AIM2MAIN sample, at the $\mathrm{p}<0.01$ level, indicating that firms seeking promotion to the main market have a growth bias and do well when the growth style premium is positive. The coefficients on industry residual returns are not significant for either group of firms. ${ }^{8}$ Excess returns for both groups of firms are negatively related to changes in bid-ask spreads as evidenced by the negative coefficients which are significant at the $p<0.01$ level. Both samples of firms have positive coefficients on the daily volume of shares traded scaled by total shares outstanding, significant at the $\mathrm{p}<0.05$ level for the AIM2MAIN sample and at the $\mathrm{p}<0.01$ level for the MAIN2AIM sample. Changes in the percentage free float are not a significant factor in explaining excess returns for either sample, while lagged firm returns are positively associated with current returns in both samples, with coefficients significant at the $p<0.01$ level.

We carried out a number of robustness checks including: (1) not substituting market returns for firm returns on days when no trading or price change occurred; (2) excluding firms in which the total trading volume in the year prior to implementation was less than $1 \%$ of shares outstanding; (3) varying the model specification to include additional lags on the control variables; (4) omitting non-significant control variables such as the free float; (5) imposing winsorizations of $2.5 \%$ on each tail; (6) partitioning the data into quartiles of calendar time for implementation dates, quartiles of market capitalization and quartiles of

\footnotetext{
${ }^{8}$ An earlier version of this paper, reported a model which omitted the bid-ask spread, size, style and other liquidity variables and found that industry residuals are significant. However, further analysis reveals that their significance is subsumed when the above variables are no longer omitted.
} 
average bid-ask spread one year prior to implementation. In all of our robustness checks we obtained qualitatively similar results with consistent coefficient signs on the key variables of interest, although significance levels naturally vary.

Overall the results reported in table 4 demonstrate that after taking into account all of the control variables in model I, the market reacts positively to announcements of migrations from AIM to the main market, and negatively to announcements and implementation of migrations in the opposite direction. However, following migration, return patterns are reversed, consistent with hypotheses $1 \& 2$.

\subsection{Cross sectional analysis}

Model I coefficients are estimated for each firm in the respective samples and then averaged across samples and reported in table 4. The key relationships of interest in model I are represented by: (a) the intercept coefficient, showing the model-adjusted daily average abnormal returns; (b) the intercept dummy variable coefficient showing incremental average daily abnormal returns observed post implementation; and (c) the separate dummy variable coefficients recording the announcement day and implementation day abnormal returns respectively. As systematic variations of these abnormal returns between firms may not be captured by the averaging of model I coefficients reported in table 4 , we undertake a cross sectional analysis of the four key coefficients from model I. This is achieved by setting each key coefficient as the dependent variable in four variations of a cross sectional regression of model II; i.e., one variation for each coefficient of interest. The independent variables in model II are listed in tables 5 and 6 for the AIM2MAIN and MAIN2AIM samples respectively. For each firm they include: the model I coefficients other than the respective dependent variable in model II; the market value ranking on the implementation day across the whole sample migration category; the average bid ask spread; the standardized daily trading volume; the proportion of no price days, the average free float percentage over the 
period $\mathrm{t}_{-255}$ through $\mathrm{t}_{-6}$; the implementation lag in trading days; the death lag in trading days; and the amount of explanation provided to justify the switch.

The basic premise of model II is that there may be associations between individual firm characteristics. For example, AIM2MAIN firms with a high sensitivity to the value style premium might perform better post implementation than firms with a low sensitivity to this factor. Model II investigates this possibility by regressing coefficients estimated on the VMG factor in model I on the intercept dummy coefficients also estimated in model I. In table 5, the positive coefficient for 'Model I VMG coefficient', significant at the $\mathrm{p}<0.05$ level, indicates that sensitivity to the value style premium is indeed positively related to post implementation performance of AIM2MAIN firms. Investigation of between-firm variation in model I coefficients with the aid of a cross sectional regression arguably allows a richer exploration of the data than a panel estimation using firm fixed effects. This is because the cross sectional regression takes into account between firm variations in both slope and intercept coefficients in model 1.

Insert Table 5 about here

Comparison of tables 5 and 6 confirms that for both groups of firms, the model II intercept coefficients estimated for each of the four dependent variables are not significant. This indicates that systematic variation between firms in the key model I coefficients is explained by model II. For the AIM2MAIN sample (table 5) it is evident that firms which exhibit the greatest abnormal returns undergo the greatest reversal in fortunes following implementation, as evidenced by the negative relationship between the model I intercept dummy and model I intercept coefficients, significant at $\mathrm{p}<0.05$. This is consistent with the prediction of hypothesis 3 to the effect that pre-implementation abnormal returns of firms transferring to the main market are inversely related post implementation abnormal returns. It is also evident that AIM2MAIN firms with a higher sensitivity to the market return appear 
to have lower overall abnormal returns, although this is only marginally significant at $\mathrm{p}<$ 0.10. Sensitivity to market returns is also positively associated with announcement day abnormal returns and is significant at the $\mathrm{p}<0.05$ level. Firms whose sensitivity to market returns increase following promotion to the main market also have a smaller return reversal following implementation as evidenced by the negative relationship between the model I intercept dummy and the market interaction dummy, significant at the $p<0.05$ level. Given that liquidity is controlled for in model II, this result is unlikely to be an artifact of liquidity variations between firms. The results imply that firms that have a higher sensitivity to market returns are more efficiently priced so that there is less pre and post announcement information leakage and less opportunity for mispricing to result in either negative or positive abnormal returns.

More liquid firms are associated with higher post implementation abnormal returns and higher announcement day abnormal returns, as evidenced by the negative coefficients on average bid-ask spread and the positive coefficients on trading volume for both of these dependent variables. AIM2MAIN firms with a higher sensitivity to the value-style factor are associated with higher post implementation returns, while firms with a higher sensitivity to the small firm premium are associated with lower announcement day abnormal returns.

Insert Table 6 about here

Corresponding model II coefficients for the MAIN2AIM sample are reported in table 6. Once again, none of the intercept coefficients are significant. In fact, relatively few of the model II coefficients are significant, indicating that little systematic variation is lost in the averaging of model I coefficients discussed earlier. The variable named 'average proportion of total justification categories' refers to the number of justification categories used in each firm's announcement to justify its migration, divided by the total number of justification 
categories identified in table 1. The amount of justification appears to be marginally significant at the $\mathrm{p}<0.10$ level and positively associated with overall model I adjusted abnormal returns, indicating that firms with better shareholder communication perform better. The pre-implementation bid-ask spread is negatively associated with the change in abnormal returns post implementation, significant at the $\mathrm{p}<0.05$ level, while volume is positively associated with overall model I adjusted abnormal returns, although only marginally significant at the $\mathrm{p}<0.10$ level. Firms with a higher free float exhibit more negative implementation day abnormal returns and more positive post implementation abnormal returns, although this effect is again only marginally significant at the $\mathrm{p}<0.10$ level. Sensitivity to the value-style factor is positively associated with implementation day returns and significant at the $\mathrm{p}<0.05$ level. Contrary to hypothesis 4 , we do not find any evidence of an inverse relationship between pre and post implementation abnormal returns for firms transferring from the main section to AIM. Overall, the weak significance of the model II coefficients with respect to MAIN2AIM is reassuring as it implies that most of the relevant information is captured by model I, with little new information added by model II.

\subsection{Changes in liquidity associated with listing migrations}

Apart from providing evidence in support of hypotheses $1 \& 2$, it is also evident from table 4 and the literature reviewed in section 3 that increases in liquidity are positively associated with excess returns, particularly with regards to the bid-ask spread and daily trading volume. Anticipated improvements in liquidity are frequently cited as a motivation for a listing migration when the decision is announced, as reported in table 1 . Therefore, we examine firm liquidity measures in the 250 days prior to implementation, the implementation date and the 250 days following implementation. The three measures of liquidity examined for each group of firms are: the bid-ask spread, the volume of shares traded as a percentage of shares outstanding and the rolling five day proportion of days for each firm when both: (a) no price change is recorded, and (b) no shares are traded. We refer 
to this final liquidity proxy as the 'no price day proportion' (NPDP). The NPDP is arguably comparable to a combination of the zero lots liquidity metric proposed by Lesmond, Ogden and Trzcinka (1999) and the liquidity measure of Liu (2006). The zero lots measure records the proportion of days in which a security yields a return of zero, whereas the Liu method records the scaled proportion of zero volume days. We justify our more exacting measure of liquidity on the grounds that zero return days in which volume is non-zero provide an indication of transaction prices that can be achieved. When new information is released, it is possible for the price to change without any securities changing hands. Our NPDP measure only records the proportion of days when it can be effectively argued that no price existed, i.e. when it is impossible to know either at what price, or at what depth, securities could have been traded. The imperfect correlation between different measures of liquidity (Goyenko, Holden and Trzcinka, 2009) reflects different information held in these measures, motivating our examination of three separate indicators.

Insert Figure 5 about here

The bid-ask spread represents a substantial portion of an investor's round trip transaction costs; therefore, other things being equal, a reduction in the bid ask spread should increase the value of the firm. The volume of shares traded provides a proxy for market depth, in that if daily trading volume increases, it implies that an investor can undertake larger transactions in a firm's stock without moving the price, because the marginal information content per given volume of shares in an individual trade is lower. Hence, other things being equal, a stock that is traded in higher volumes should have less risk for an investor as they are more likely to be able to enter, or exit from their position 
without affecting the price. ${ }^{9}$ Both of these variables are included in model I and the coefficient signs are consistent with that intuition. The trimmed sample means of the rolling five-day moving average percentage bid-ask spreads are reported in figure 5 together with 95\% confidence intervals based upon standard errors estimated using the full, untrimmed, distribution. From panel A of figure 5, it is evident that for AIM2MAIN firms the mean bidask spread declines by approximately $0.75 \%$ from $4 \%$ to around $3.25 \%$ in the year prior to implementation. However, in the year following implementation, average bid ask spreads subsequently revert to a level close to that at the beginning of the event window.

For MAIN2AIM firms moving in the opposite direction, panel $\mathrm{B}$ of figure 5 indicates that the pattern is a slightly exaggerated mirror image of that in the AIM2MAIN sample. Average bid-ask spreads increase by approximately $1.5 \%$ from a mean of $9.3 \%$ one year prior to implementation to $10.8 \%$ just prior to implementation before declining back to 9.3\% again by the end of the event window. These temporary variations in bid-ask spreads in the two samples, taken together with the significant negative coefficients in model I, suggest that some, but not all of the change in firm values in the year prior to and following implementation exhibited in figures 2 to 4 , can be explained by changes in bid ask spreads. Furthermore, it is evident from figure 5, that firms in the MAIN2AIM sample have a higher average bid-ask spread (c. 9.5\%) than firms in the AIM2MAIN sample (c. 3.5\%) over the whole event window.

Insert Figure 6 about here

\footnotetext{
${ }^{9} \mathrm{NPD}$, the third liquidity variable examined is not included in model I because: (a) it substantially consists of the lower tail of the volume variable, i.e. when volume is zero, and it is likely to be highly correlated with volume as a result and; (b) firm returns on NPDs are unreliable by definition and in order to mitigate thin trading bias, in our estimation of model I coefficients, market excess returns are substituted for firm returns on NPDs making the rolling NPD proportion a potentially misleading variable to include in model I. Nonetheless, the NPD proportion is an inverse measure of liquidity as it captures the proportion of a firm's trading time when trading volume and price changes are zero, i.e. the proportion of trading time spent in the least liquid state.
} 
The average daily trading volumes over the 501 day event window are plotted in figure 6 for each of the two samples. It is clear from panel A of figure 6 that in the AIM2MAIN sample the cross sectional (between-firm) variation in average trading volume is noisy and that this noise subsequently subsides following implementation of the listing change. From panel B of figure 6 it is evident that firms in the MAIN2AIM sample have a somewhat lower average trading volume compared to firms in the AIM2MAIN sample, but that this average increases significantly from around 100 days prior to, during and following implementation, before declining back to original levels by around 100 trading days after implementation. Given the positive coefficients on trading volume estimated in model I it would seem that increases in trading volume around implementation may, to some extent, offset the effect of increases in bid ask spreads for the MAIN2AIM sample.

The values of our final measure of liquidity, NPDP, are plotted in figure 7 . Once again, the pattern is somewhat different for the two samples. For the AIM2MAIN sample, reported in panel A, average NPDP declines from $30 \%$ one year before implementation to under $15 \%$ in the month before implementation. However, it subsequently reverts to a level of around $28 \%$ within 75 trading days of implementation where it remains until the end of the event window. The time series pattern in the MAIN2AIM sample, reported in panel B, is more extreme. The NPDP remains relatively stable at around $37 \%$ until 50 days before implementation, before declining rapidly to reach a low of $13 \%$ one week after implementation, and then rising rapidly until 28 days after implementation, when it gradually increases to $38 \%$ by the end of the event window.

Insert Figure 7 about here

The patterns observed in the bid ask spread are supportive of hypotheses 5 and 6 during the period immediately surrounding the implementation date for both groups of 
firms, while the changes in trading volume and NPDP in the same period are consistent with a price pressure effect as investors rebalance their portfolios. Furthermore, the changes observed for all three measures are transitory for both groups of firms as there is little difference in liquidity one year before and one year after the migrations. The increase in bidask spread concurrent with an increase in trading volume and a reduction in NPDP observed during the implementation period in the MAIN2AIM sample raises the possibility that trading volume and liquidity may be negatively correlated during the implementation period in a manner consistent with the model of Kim and Verrecchia (1994).

In summary, we can say that some, but not all, of the variation in firm values around the implementation of a listing switch can be explained by changes in liquidity. Leitterstorf, Nicoletti, and Winkler (2008) fail to find support for the idea that liquidity consistently improves for firms switching from the AIM to the main market or declines for firms switching the other way. We go further by examining the daily variations in liquidity, and while we document considerable changes in all three measures in the period leading up to and during the implementation of a listing switch, by the end of the 501 day event window the three liquidity measures revert to their original levels. Hence, any liquidity changes arising as a result of a listing switch are transitory. Our results are consistent with those of Chuang, Liao and Yu (2009) who find only a temporary improvement in liquidity around exchange listings in Taiwan.

\section{Discussion and conclusions}

On average, firms moving from the AIM to the main market of the LSE experience positive abnormal returns before the announcement date. After adjusting for size, style and liquidity changes, additional positive abnormal returns are also observed on the day of the announcement. The opposite results are found for firms migrating downwards from the main market to AIM. It thus appears that announcements of the intention to move up and down are associated with good and bad news, respectively. Both categories of switching 
firm experience a reversal in abnormal returns following the implementation date. For firms transferring down from the main market to the AIM, the improved performance post implementation may be a reward to shareholders for bearing increased levels of agency risk. In contrast, because investors value the higher bonding requirements of the main market, firms transferring up to the main market experience positive abnormal returns on the announcement days but subsequently have negative abnormal returns that reflect the lower cost of equity capital as a result of reduced agency risk. An alternative explanation for the pattern in abnormal returns is that investors interpret transfers as a signal about firms' future trading prospects. However, if this is the case they appear to overreact to both positive and negative signals on the announcement and implementation days, while subsequent developments do not justify the level of optimism and pessimism generated by the signals.

Our conclusions are subject to the caveat that we have not measured the relationship between bonding costs and firm performance directly. However, the fact that we include a wide variety of control variables to eliminate other possible explanations for the performance of switching firms mitigates this concern, as does the fact that our results are robust to the employment of various alternative measurements. For example, although we observe changes in liquidity leading up to, during and following implementation of a listing migration for both groups, these changes in liquidity are transitory and we find no discernable differences in three liquidity measures one year before and one year after implementation. Our controls demonstrate that liquidity changes do not fully account for the changes in firm valuation and returns surrounding migrations. Likewise, examination of the survival rates of switching firms provides little evidence that differences in bankruptcy rates, pre and post migration, are a competing explanation for our results.

Firms transferring from the AIM to the main section exhibiting the highest average daily abnormal returns prior to the listing change exhibit the lowest average daily abnormal returns following the listing change. This reversal of fortunes suggests that the management of these firms may be exploiting information asymmetry in order to time their firm's 
promotion to the main market, perhaps in order to secure more favourable employment contracts or to dispose of personal equity stakes.

Bearing in mind both the changes in firm valuation and cost of capital arising as a result of listing changes, and also the tax consequences of listing changes for investors, these findings are relevant to both AIM and main market investors. More than double the number of firms moved down to the AIM from the main market as moved in the opposite direction. The median size of firms transferring to the main market is thirteen and a half times larger than firms moving down to the AIM. Hence it seems plausible that firms moving down have reached a size at which the additional bonding costs of maintaining a main market listing are no longer outweighed by the reduced cost of capital arising from the lower agency risks of a main market listing. 


\section{References}

Amihud, Y., Mendelson, H., 1986. Asset pricing and bid-ask spread. Journal of Financial Economics 17, $223-249$.

Amira, K., Muzere, M. L., 2011. Competition among stock exchanges for equity. Journal of Banking and Finance 35, 2355-2373.Arcot, S., Black, J., Owen, G., 2007. From local to global: the rise of AIM as a stock market for growing companies. Report commissioned by London Stock Exchange from The London School of Economics and Political Science.

Bacmann, J.F., Dubois, M., Ertur, C., 2002. Valuation effects of listing on a more prominent segment of the stock market: evidence from France. European Financial Management 8, 479 $-493$.

Baker, H. K., Edelman, R. B., 1992a. AMEX-to-NYSE transfers, market microstructure, and shareholder wealth. Financial Management 21, 60 - 72.

Baker, H. K., Edelman, R. B., 1992b. The effects on spread and volume of switching to the NASDAQ national market system. Financial Analysts Journal 48, 83 - 88.

Bebchuk, L.A., 2005. The case for increasing shareholder power. Harvard Law Review 118, $833-914$.

Bebchuk, L.A., 2007. The myth of the shareholder franchise. Virginia Law Review 93, 675 $-732$.

Becht, M., Franks, J., Rossi, S., 2009. Returns to shareholder activism: evidence from a clinical study of the Hermes UK Focus Fund. Review of Financial Studies 22, 3093 - 3129.

Brau, J.C., Fawcett, S.E., 2006. Initial public offerings: an analysis of theory and practice. The Journal of Finance 61, $399-436$.

Carpentier, C., Cumming, D., Suret, J. M., 2011. The Valuation Effect of Listing Standards: An Analysis of Canadian and US IPOs. Working Paper, February. 
Carlson, M., Fisher, A., Giammarino, R., 2010. SEO risk dynamics. Review of Financial Studies 23, $4026-4077$.

Carvalho, A.G., Pennacchi, G.G., 2012. Can a stock exchange improve corporate behavior? Evidence from firms' migration to premium listings in Brazil. Journal of Corporate Finance $18,883-903$.

Chemmanur, T.J., Fulghieri, P., 2006. Competition and co-operation among exchanges: A theory of cross-listing and endogenous listing standards. Journal of Financial Economics 82, $455-489$.

Chuang, H.L, Liao, T.L, Yu, M.T., 2009. Price Pressure around Exchange Listings. Working Paper, Department of Economics, National Tsing Hua University, Taiwan.

Clyde, P., Schultz, P., Zaman, M., 1997. Trading costs and exchange delisting: the case of firms that voluntarily move from the American stock exchange to the NASDAQ. The Journal of Finance 52, $2103-2112$.

Coffee, J.C., 1999. The future as history: the prospects for global convergence in corporate governance and its implications. Northwestern University Law Review 93, 641 - 708.

DeAngelo, H., DeAngelo, L., Stulz, R.M., 2010. Seasoned equity offerings, market timing and the corporate lifecycle. Journal of Financial Economics 95, 275 - 295.

Dimson, E., 1979. Risk measurement when shares are subject to infrequent trading, Journal of Financial Economics 7, 197 - 226.

Doidge, C., Karolyi, G.A., Stulz, R.M., 2007. Why do countries matter so much for corporate governance? Journal of Financial Economics 86, 1 - 39.

Easley, D., O’Hara, M., 2010. Liquidity and valuation in an uncertain world. Journal of Financial Economics 97, 1 - 11.

Ellul, A., Pagano, M., 2006. IPO underpricing and after-market liquidity. Review of Financial Studies 19, $381-421$. 
Espenlaub, S., Khurshed, A. Mohamed, A., 2012. IPO survival in a reputational market. Journal of Business Finance and Accounting 33, 427 - 463.

Fama, E.F., French, K.R., 1993. Common risk factors in the returns on stocks and bonds. Journal of Financial Economics 33, 3 - 56.

Fang, V. W., Noe, T. H., Tice, S., 2009, Stock market liquidity and firm value. Journal of Financial Economics 94: 150-169.

Financial Reporting Council. 2010. The UK Corporate Governance Code. Available at: http://www.frc.org.uk/documents/pagemanager/Corporate_Governance/UK Corp Gov Code June 2010.pdf

Foerster, R., Karolyi, A., 1999. The effects of market segmentation and investor recognition on asset prices: evidence from foreign stocks listing in the United States. Journal of Finance $54,981-1013$.

Gerakos, J. J., Lang, M. H., Maffett, M. G., 2012. Listing Choices and Self-Regulation: The Experience of the AIM. Chicago Booth Research Paper No. 11-04. Available at SSRN: http://ssrn.com/abstract=1739137

Glosten, L.,Milgrom, P., 1985. Bid, ask, and transaction prices in a specialist market with heterogeneously informed traders. Journal of Financial Economics 14, 71-100.

Goyenko, R., Holden, C., Trzcinka, C., 2009. Do liquidity measures measure liquidity? Journal of Financial Economics 92, 153-181.

Hail, L., Leuz, C., 2009. Cost of capital effects and changes in growth expectations around U.S. cross-listings. Journal of Financial Economics 93, 428 - 454.

Harris, A. D., 2006. The impact of hot issue markets and noise traders on stock exchange listing standards. University of Toronto Law Journal 56, 223 - 280. 
Jenkinson, T., Ramadorai, T., 2012. Does One Size Fit All? The Consequences of Switching Markets with Different Regulatory Standards. Working Paper, Said Business School, University of Oxford and CEPR.

Kadlec, G., McConnell, J., 1994. The effect of market segmentation and illiquidity on asset prices: Evidence from exchange listings. Journal of Finance 49, $611-636$.

Kim, O., Verrecchia, R.E., 1994. Market liquidity and volume around earnings announcements. Journal of Accounting Economics 17, $41-67$.

Kraus, A., Stoll, H.R., 1972. Price impacts of block trading on the New York Stock Exchange. Journal of Finance 27, $569-588$.

Lamba, A. S., Ariff, M., 1997. The information content of firms switching from section 2 to section 1 of the Tokyo stock exchange. Pacific-Basin Finance Journal 5, $441-463$.

Lamba, A. S., Khan, W.A., 1999. Exchange listings and delistings: the role of insider information and insider trading. The Journal of Financial Research 22, $131-146$.

La Porta, R., Lopez-De-Silanes, F., Shleifer, A., Vishny, R.W., 1997. Legal determinants of external finance. Journal of Finance 52, $1131-1150$.

La Porta, R., Lopez-De-Silanes, F., Shleifer, A., Vishny, R.W., 1998. Law and Finance. The Journal of Political Economy 106, 1113 - 1155.

La Porta, R., Lopez-De-Silanes, F., Shleifer, A., 1999. Corporate ownership around the world. Journal of Finance 54, 471 - 517.

Lee, G., Masulis, R., 2009. Seasoned equity offerings: Quality of accounting information and expected flotation costs, Journal of Financial Economics 92, $443-469$.

Lee, G., Masulis, R., 2011. Do more reputable financial institutions reduce earningsmanagement by IPO issuers? Journal of Corporate Finance 17, 982 - 1000. 
Leitterstorf, S. Nicoletti, P., Winkler, C., 2008. The UK Listing Rules and Firm Valuation. Financial Services Authority Occasional Paper Series 28, available at: http://www.fsa.gov.uk/pubs/occpapers/op28.pdf

Lel, U., Miller, D., 2008. International crosslisting, firm performance and top management turnover: A test of the bonding hypothesis. Journal of Finance 63, 1897-937.

Lesmond, D., Ogden, J., Trzcinka, C., 1999. A new estimate of transaction costs. Review of Financial Studies 12, $1113-41$.

Leuz, C., Triantis, A., Wang, T.Y., 2008. Why do firms go dark? Causes and economic consequences of voluntary SEC deregistrations. Journal of Accounting Economics 45, 181 208.

Litvak, K. 2009. The Relationship Among U.S. Securities Laws, Cross-Listing Premia, and Trading Volumes. CELS 2009 4th Annual Conference on Empirical Legal Studies. Available at: $\underline{\text { http://ssrn.com/abstract }=1443590}$

Liu, W., 2006. A liquidity-augmented Capital Asset Pricing Model. Journal of Financial Economics 82, $631-671$.

London Stock Exchange, 2010. AIM Rules for Companies. February. Available at: http://www.londonstockexchange.com/companies-and-advisors/aim/advisers/rules/aim-

$\underline{\text { rules-for-companies.pdf }}$

London Stock Exchange, 2011a. List of all companies. Accessed in April 2011 at: http://www.londonstockexchange.com/statistics/companies-and-issuers/companies-andissuers.htm London Stock Exchange, 2011b. New Issues and IPO Summary. Accessed in March 2011 at: $\underline{\text { www.londonstockexchange.com/statistics/new-issues...issues/new-issues.xls }}$ Macey, J. R., O'Hara, M., 2002. The economics of stock exchange listing fees and listing requirements. Journal of Financial Intermediation 11, 297 - 319. 
MacNeil, I., Li, X., 2006. “Comply or explain”: market discipline and non-compliance with the Combined Code. Corporate Governance: An International Review 14, 486 - 496.

Mallin, C., Ow-Yong, K., 1998. Corporate Governance in small companies - the Alternative Investment Market. Corporate Governance: An International Review 6, 224 - 232.

Mallin, C.,Ow-Yong, K., 2008. Corporate Governance in the Alternative Investment Market (AIM) Firms. Institute of Chartered Accountants of Scotland, Research Report.

Merton, R., 1987. Presidential address: a simple model of capital market equilibrium with incomplete information. Journal of Finance 42, $483-510$.

Nielsson, U., 2012. Do Less Regulated Markets Attract Lower Quality Firms? Evidence from the London AIM Market. Journal of Financial Intermediation, doi: http://dx.doi.org/10.1016/j.jfi.2012.11.005

Pagano, M., Roell, A., Zechner, J., 2002. The geography of equity listing: why do companies list abroad? Journal of Finance 57, 2651 - 2694.

Piotrosky, J.D., Srinivasan, S., 2008. Regulation and bonding: the Sarbanes-Oxley Act and the flow of international listings, Journal of Accounting Research 46, $383-425$.

Scholes, M.S., 1972. The market for securities: substitution versus price pressure and the effect of information on share price. Journal of Business 45, 179-211.

Skaife, H.A., Collins, D.W., LaFond, R., 2004. Corporate Governance and the Cost of Capital, Working paper available at: http://ssrn.com/abstract=639681.

Snell, D., O'Brien, S., 2008. Corporate Governance and AIM: An assessment of the governance procedures adopted by AIM companies. London: PricewaterhouseCoopers, available at: http://www.pwc.co.uk/pdf/corporate_governance_aim.pdf

Stulz, R., 1999. Globalization, corporate finance, and the cost of capital. Journal of Applied Corporate Finance 26, 3-28.Tse, Y., Devos, E., 2004. Trading costs, investor recognition 
and market response: An analysis of firms that move from the Amex (Nasdaq) to Nasdaq (Amex). Journal of banking \& Finance 28, 63 - 83.

Vismara, S., Paleari, S., Ritter, J.R., 2012. Europe's second market for small companies. European Financial Management 18, 352 - 388. 
Table 1

\section{Justifications for a Change of Listing}

AIM2MAIN firms are those that transfer from the AIM to the main market. MAIN2AIM firms are those transferring in the opposite direction. The first announcement of the intended change of listing was searched for a statement justifying the change. Statements were then grouped into the categories identified below, the titles of which record the meaning of, or paraphrase, the justifications provided by the individual firms. Some firms gave multiple justifications; hence, the total number of justifications in each sample is greater than the total number of firms despite the fact that $42.3 \%$ of AIM2MAIN and $15.6 \%$ of MAIN2AIM firms do not give any justification. The average disclosure proportion reflects the average of the number of justifications given by each firm divided by the total number of justification categories identified below. The category "shareholder protection statement" records firms in the MAIN2AIM sample that found it necessary to reassure investors that their interests would not be adversely affected by the switch.

\begin{tabular}{lcccc}
\hline Justification Category & $\begin{array}{c}\text { AIM2MAIN } \\
\text { No. \& \% }\end{array}$ & \multicolumn{2}{c}{$\begin{array}{c}\text { MAIN2AIM } \\
\text { No. \& \% }\end{array}$} \\
\hline No justification & 47 & $42.3 \%$ & 41 & $15.6 \%$ \\
Growth and/or appropriate for firm's size & 40 & $36.0 \%$ & 131 & $49.8 \%$ \\
Raised profile of company or market & 39 & $35.1 \%$ & 6 & $2.3 \%$ \\
Increase investor base & 36 & $32.4 \%$ & 20 & $7.6 \%$ \\
Improve liquidity/appropriate for current liquidity & 30 & $27.0 \%$ & 12 & $4.6 \%$ \\
Placing/capital raising concurrent with switch & 11 & $9.9 \%$ & 38 & $14.4 \%$ \\
Ease of future capital raising & 4 & $3.6 \%$ & 14 & $5.3 \%$ \\
Ease of future acquisitions & 2 & $1.8 \%$ & 38 & $14.4 \%$ \\
Attract staff & 2 & $1.8 \%$ & 1 & $0.4 \%$ \\
Cost savings, simplification of reporting/regulation & 0 & 0 & 127 & $48.3 \%$ \\
General flexibility regarding corporate transactions & 0 & 0 & 105 & $39.9 \%$ \\
Tax benefits for investors & 0 & 0 & 34 & $12.9 \%$ \\
Restructuring/refocusing/refinancing/write down & 0 & 0 & 28 & $10.6 \%$ \\
Violates minimum 25\% free-float rule, or similar & 0 & 0 & 17 & $6.5 \%$ \\
Suitable for existing investor base & 0 & 0 & 15 & $5.7 \%$ \\
High proportion of private investors & 0 & 0 & 4 & $1.5 \%$ \\
Shareholder protection statement & 0 & 0 & 37 & $14.1 \%$ \\
\hline Total number of justifications in each sample & 164 & & 616 & \\
Total number of firms in each sample & 111 & & 262 & \\
Average proportion of total justification categories & NA & $18.5 \%$ & NA & $15.0 \%$ \\
Maximum proportion of total justification categories & NA & $87.5 \%$ & NA & $53.3 \%$ \\
\hline
\end{tabular}


Table 2

\section{Characteristics of Transferring Firms}

AIM2MAIN firms are those that transfer from the AIM to the main market. MAIN2AIM firms are those transferring in the opposite direction. Acronyms in parenthesis are the Datastream industry codes. Other abbreviations are as follows: number of observations (No.) largest observation (Max.), smallest observation (Min.), average (Av.), market capitalization (Mkt. Cap.), implementation (Imp.), bid-ask spread (BAS), no price days in which both trading volume and price changes are zero (NPD), proportion (Prop.).

\begin{tabular}{|c|c|c|c|c|}
\hline \multirow{2}{*}{$\begin{array}{l}\text { Firm Characteristics } \\
\text { Total }\end{array}$} & \multicolumn{2}{|c|}{ I2MAIN No. \& \% } & \multicolumn{2}{|c|}{ MAIN2AIM No. \& \% } \\
\hline & 111 & $(100 \%)$ & 262 & $(100 \%)$ \\
\hline Consumer Services (CNSMS) & 24 & $(22 \%)$ & 44 & $(17 \%)$ \\
\hline Financials (FINAN) & 31 & $(28 \%)$ & 32 & $(12 \%)$ \\
\hline Industrials (INDUS) & 18 & $(16 \%)$ & 79 & $(30 \%)$ \\
\hline Technology (TECNO) & 14 & $(13 \%)$ & 41 & $(16 \%)$ \\
\hline Healthcare (HLTHC) & 11 & $(10 \%)$ & 11 & $(4 \%)$ \\
\hline Oil \& Gas (OILGS) & 5 & $(5 \%)$ & 4 & $(2 \%)$ \\
\hline Telecom (TELCM) & 3 & $(3 \%)$ & 3 & $(1 \%)$ \\
\hline Utilities (UTILS) & 3 & $(3 \%)$ & 0 & $(0 \%)$ \\
\hline Basic Materials (BMAT) & 1 & $(1 \%)$ & 6 & $(2 \%)$ \\
\hline Consumer Goods (CNSMG) & 1 & $(1 \%)$ & 41 & $(16 \%)$ \\
\hline Min. Imp. lag & & 0 & & 10 \\
\hline $25^{\text {th }}$ percentile of the Imp. lag & & 20 & & 21 \\
\hline $50^{\text {th }}$ percentile of the Imp. lag & & 39 & & 23 \\
\hline $75^{\text {th }}$ percentile of the Imp. lag & & 115 & & 40 \\
\hline Max. Imp. Lag & & 607 & & 201 \\
\hline Min. Mkt. Cap. Imp. Day & & $£ 1.6 \mathrm{~m}$ & & $£ 0.3 \mathrm{~m}$ \\
\hline $25^{\text {th }}$ percentile of the Mkt. Cap. Imp. Day & & $£ 49.6 \mathrm{~m}$ & & $£ 4.7 \mathrm{~m}$ \\
\hline $50^{\text {th }}$ percentile of the Mkt. Cap. Imp. Day & & $£ 122.5$ & & $£ 9.1 \mathrm{~m}$ \\
\hline $75^{\text {th }}$ percentile of the Mkt. Cap. Imp. Day & & $£ 255.3$ & & $£ 19.7 \mathrm{~m}$ \\
\hline Max. Mkt. Cap. Imp. Day & & $£ 1,098 \mathrm{~m}$ & & $£ 338 \mathrm{~m}$ \\
\hline Min. Av. BAS $\mathrm{t}-255$ through $\mathrm{t}-6$ & & $0.4 \%$ & & $1.5 \%$ \\
\hline $25^{\text {th }}$ percentile of Av. BAS $t-255$ through $t-6$ & & $2.1 \%$ & & $6.0 \%$ \\
\hline $50^{\text {th }}$ percentile of Av. BAS $t-255$ through $t-6$ & & $3.2 \%$ & & $8.7 \%$ \\
\hline $75^{\text {th }}$ percentile of Av. BAS $t-255$ through $t-6$ & & $4.5 \%$ & & $12.1 \%$ \\
\hline Max. Av. BAS $\mathrm{t}-255$ through $\mathrm{t}-6$ & & $22.6 \%$ & & $37.1 \%$ \\
\hline Min. NPD Prop. $\mathrm{t}-255$ through $\mathrm{t}-6$ & & 0 & & 0 \\
\hline $25^{\text {th }}$ percentile NPD Prop. $t-255$ through $t-6$ & & 0 & & $6.8 \%$ \\
\hline $50^{\text {th }}$ percentile NPD Prop. $t-255$ through $t-6$ & & $6.0 \%$ & & $26.6 \%$ \\
\hline $75^{\text {th }}$ percentile NPD Prop. $t-255$ through $t-6$ & & $27.2 \%$ & & $58.4 \%$ \\
\hline Max. NPD Prop. $t-255$ through $t-6$ & & $85.8 \%$ & & $100 \%$ \\
\hline
\end{tabular}


Table 3

Firms Dying Between the Implementation Date and the $4^{\text {th }}$ March 2011

AIM2MAIN firms are those that transfer from the AIM to the main market. MAIN2AIM firms are those transferring in the opposite direction. Death lag refers to the number of trading days between the implementation date and firm death. The final check for dead firms was made at the end of the study period on the $4^{\text {th }}$ March 2011. Datastream classifies firms which are inactive, but have not been taken over, suspended, or delisted, as "dead - dead".

\begin{tabular}{|c|c|c|c|c|}
\hline \multirow{2}{*}{$\begin{array}{l}\text { Death period from implementation date } \\
\text { Within } 1 \text { year ( } 250 \text { trading days })\end{array}$} & \multicolumn{2}{|c|}{ AIM2MAIN } & \multicolumn{2}{|c|}{ MAIN2AIM } \\
\hline & 2 & $(2 \%)$ & 23 & $(9 \%)$ \\
\hline Between 1 and 2 years & 15 & $(15 \%)$ & 24 & $(9 \%)$ \\
\hline Between 2 and 3 years & 5 & $(5 \%)$ & 18 & $(7 \%)$ \\
\hline Between 3 and 5 years & 14 & $(13 \%)$ & 33 & $(13 \%)$ \\
\hline More than 5 years & 46 & $(41 \%)$ & 132 & $(50 \%)$ \\
\hline $\begin{array}{l}\text { Moved }<5 \text { years before } 4^{\text {th }} \text { March } 2011 \\
\text { and alive at } 4^{\text {th }} \text { March } 2011\end{array}$ & 30 & $(27 \%)$ & 33 & $(13 \%)$ \\
\hline Total deaths up to $4^{\text {th }}$ March 2011 & 58 & $(52 \%)$ & 136 & $(52 \%)$ \\
\hline Total number of switching firms & 111 & $(100 \%)$ & 262 & $(100 \%)$ \\
\hline \multicolumn{5}{|l|}{ Datastream Death Category } \\
\hline Delisted & 4 & $(5 \%)$ & 20 & $(8 \%)$ \\
\hline Suspended & 3 & $(2 \%)$ & 4 & $(2 \%)$ \\
\hline Taken Over & 7 & $(6 \%)$ & 11 & $(4 \%)$ \\
\hline Dead - dead (unclassified) & 44 & $(40 \%)$ & $\begin{array}{c}10 \\
1 \\
\end{array}$ & $(63 \%)$ \\
\hline
\end{tabular}


Table 4

Return generating model I variables, coefficients and $\mathbf{t}$ - statistics

The dependent variable is the firm daily excess return. Least squares coefficient estimates are averaged across the respective samples.

\begin{tabular}{|c|c|c|}
\hline \multicolumn{3}{|l|}{ Panel A: AIM2MAIN sample } \\
\hline Independent variables & $\begin{array}{l}\text { Mean } \\
\text { coefficient }\end{array}$ & $t$ - statistics \\
\hline Intercept (average model adjusted excess return) & -0.001 & -1.03 \\
\hline $\begin{array}{l}\text { Intercept dummy (change in excess return following } \\
\text { implementation) }\end{array}$ & -0.001 & $-2.63 * * *$ \\
\hline Announcement day average abnormal return (dummy variable) & 0.022 & $2.53 * *$ \\
\hline Implementation day average abnormal return (dummy variable) & 0.002 & 0.55 \\
\hline Market interaction dummy variable & 0.064 & 1.56 \\
\hline Market excess return & 0.991 & $16.59 * * *$ \\
\hline Market return lagged one period & -0.051 & $-1.807 *$ \\
\hline Small firm factor return minus large firm factor return (SMB) & 0.541 & $10.88 * * *$ \\
\hline SMB lagged one period & -0.011 & -0.40 \\
\hline Value firm factor return minus growth firm factor return (VMG) & -0.114 & $-3.31 * * *$ \\
\hline VMG lagged one period & -0.062 & $-1.87 *$ \\
\hline Industry residual return & 0.034 & 1.44 \\
\hline Industry residual return lagged one period & 0.014 & 0.87 \\
\hline Change in $\%$ bid-ask spread & -0.004 & $-4.70 * * *$ \\
\hline Volume of shares traded as a $\%$ shares outstanding & 1.847 & $2.31 * *$ \\
\hline Free float percentage & -0.000 & -0.13 \\
\hline Firm excess return lagged one period & 0.075 & $7.57 * * *$ \\
\hline \multicolumn{3}{|l|}{ Panel B: MAIN2AIM sample } \\
\hline Independent variables & $\begin{array}{c}\text { Mean } \\
\text { coefficient }\end{array}$ & $t$ - statistic \\
\hline Intercept (average model adjusted excess return) & -0.002 & -1.03 \\
\hline $\begin{array}{l}\text { Intercept dummy (change in excess return following } \\
\text { implementation) }\end{array}$ & 0.001 & $2.10 * *$ \\
\hline Announcement day average abnormal return (dummy variable) & -0.028 & $-2.98 * * *$ \\
\hline Implementation day average abnormal return (dummy variable) & -0.018 & $-2.27 * *$ \\
\hline Market interaction dummy variable & -0.067 & $-2.29 * *$ \\
\hline Market excess return & 0.830 & $25.67 * * *$ \\
\hline Market return lagged one period & 0.005 & 0.21 \\
\hline Small firm factor return minus large firm factor return (SMB) & 0.411 & $13.52 * * *$ \\
\hline SMB lagged one period & 0.040 & 1.88 \\
\hline Value firm factor return minus growth firm factor return (VMG) & -0.009 & -0.30 \\
\hline VMG lagged one period & -0.031 & -1.13 \\
\hline Industry residual return & -0.024 & -1.12 \\
\hline Industry residual return lagged one period & 0.026 & 1.44 \\
\hline Change in $\%$ bid-ask spread & -0.012 & $-7.93 * * *$ \\
\hline Volume of shares traded as a $\%$ shares outstanding & 2.751 & $3.14 * * *$ \\
\hline Free float percentage & -0.001 & -0.82 \\
\hline Firm excess return lagged one period & 0.043 & $6.35 * * *$ \\
\hline
\end{tabular}

$* * *, * *, *$ indicate significance at the $0.01,0.05$ and 0.10 level respectively. 
Table 5

\section{AIM2MAIN cross sectional Model II coefficients and $\mathbf{t}$ - statistics}

Cross sectional model II in which dependent variables are the following model I coefficients: intercept; intercept dummy variable representing the post implementation abnormal return; the announcement day abnormal return; and the implementation day abnormal return, that were estimated for each firm in the sample. Abbreviations are: announcement (Ann.), implementation (Imp.), abnormal (Ab.), $t$ - statistics are in parenthesis. The variable "Amount of justification provided for switch" refers to the number of justification categories used by each firm divided by the number of justification categories identified in table 1 .

\begin{tabular}{|c|c|c|c|c|}
\hline \multirow[b]{2}{*}{ Independent Variables } & \multicolumn{4}{|c|}{ Model II Dependent Variables } \\
\hline & $\begin{array}{l}\text { Model I } \\
\text { Intercept }\end{array}$ & $\begin{array}{l}\text { Model I } \\
\text { Intercept } \\
\text { dummy }\end{array}$ & $\begin{array}{l}\text { Model I } \\
\text { Ann. day } \\
\text { ab. return }\end{array}$ & $\begin{array}{l}\text { Model I Imp. } \\
\text { day ab. } \\
\text { return }\end{array}$ \\
\hline Intercept & $\begin{array}{c}0.011 \\
(1.268)\end{array}$ & $\begin{array}{c}0.000 \\
(0.152)\end{array}$ & $\begin{array}{c}0.042 \\
(0.713)\end{array}$ & $\begin{array}{l}-0.006 \\
(-0.207)\end{array}$ \\
\hline Model I intercept coefficient & & $\begin{array}{c}-0.058 \\
(-2.342)^{* *}\end{array}$ & $\begin{array}{l}-0.836 \\
(-1.192)\end{array}$ & $\begin{array}{l}-0.359 \\
(-1.048)\end{array}$ \\
\hline Model I intercept dummy & $\begin{array}{c}-0.937 \\
(-2.342)^{* *}\end{array}$ & & $\begin{array}{l}-2.560 \\
(-0.907)\end{array}$ & $\begin{array}{l}1.066 \\
(0.774)\end{array}$ \\
\hline Model I Ann. day Ab. return & $\begin{array}{l}-0.018 \\
(-1.192)\end{array}$ & $\begin{array}{l}-0.003 \\
(-0.907)\end{array}$ & & $\begin{array}{c}0.008 \\
(0.151)\end{array}$ \\
\hline Model I Imp. day Ab. return & $\begin{array}{l}-0.032 \\
(-1.048)\end{array}$ & $\begin{array}{l}0.006 \\
(0.774)\end{array}$ & $\begin{array}{c}0.032 \\
(0.151)\end{array}$ & \\
\hline Model I market coefficient & $\begin{array}{c}-0.008 \\
(-1.738)^{*}\end{array}$ & $\begin{array}{l}-0.001 \\
(-1.158)\end{array}$ & $\begin{array}{c}0.079 \\
(2.577)^{* *}\end{array}$ & $\begin{array}{l}-0.017 \\
(-1.077)\end{array}$ \\
\hline $\begin{array}{l}\text { Model I market interaction } \\
\text { coefficient }\end{array}$ & $\begin{array}{c}-0.003 \\
(-0.853)\end{array}$ & $\begin{array}{c}-0.002 \\
(-2.033) * *\end{array}$ & $\begin{array}{c}0.024 \\
(0.985)\end{array}$ & $\begin{array}{c}0.013 \\
(1.147)\end{array}$ \\
\hline Model I SMB coefficient & $\begin{array}{c}0.007 \\
(1.239)\end{array}$ & $\begin{array}{c}0.002 \\
(1.435)\end{array}$ & $\begin{array}{c}-0.079 \\
(-2.116) * *\end{array}$ & $\begin{array}{c}0.002 \\
(0.120)\end{array}$ \\
\hline Model I VMG coefficient & $\begin{array}{c}0.001 \\
(0.233)\end{array}$ & $\begin{array}{c}0.002 \\
(2.524)^{* *}\end{array}$ & $\begin{array}{c}0.001 \\
(0.046)\end{array}$ & $\begin{array}{l}0.018 \\
(1.324)\end{array}$ \\
\hline $\begin{array}{l}\text { Market value percentile rank on } \\
\text { Imp. day }\end{array}$ & $\begin{array}{c}0.001 \\
(0.196)\end{array}$ & $\begin{array}{l}-0.002 \\
(-1.391)\end{array}$ & $\begin{array}{l}-0.001 \\
(-0.024)\end{array}$ & $\begin{array}{c}0.016 \\
(0.792)\end{array}$ \\
\hline $\begin{array}{l}\text { Bid ask spread average } \\
\text { percentage, } \mathrm{t}-255 \text { through } \mathrm{t}-6\end{array}$ & $\begin{array}{l}-0.049 \\
(-1.093)\end{array}$ & $\begin{array}{c}-0.024 \\
(-2.210) * *\end{array}$ & $\begin{array}{c}-0.547 \\
(-1.792)^{*}\end{array}$ & $\begin{array}{c}-0.123 \\
(-0.816)\end{array}$ \\
\hline $\begin{array}{l}\text { Standardised volume, } \mathrm{t}-255 \\
\text { through } \mathrm{t}-6\end{array}$ & $\begin{array}{c}0.002 \\
(1.558)\end{array}$ & $\begin{array}{c}0.001 \\
(3.424)^{* * *}\end{array}$ & $\begin{array}{c}0.019 \\
(2.321)^{* *}\end{array}$ & $\begin{array}{c}0.004 \\
(1.045)\end{array}$ \\
\hline $\begin{array}{l}\text { NPD proportion day, } \mathrm{t}-255 \\
\text { through } \mathrm{t}-6\end{array}$ & $\begin{array}{c}0.011 \\
(1.449)\end{array}$ & $\begin{array}{l}0.003 \\
(1.588)\end{array}$ & $\begin{array}{l}-0.045 \\
(-0.830)\end{array}$ & $\begin{array}{l}-0.028 \\
(-1.052)\end{array}$ \\
\hline $\begin{array}{l}\text { Average free float, } \mathrm{t}-255 \\
\text { through } \mathrm{t}-6\end{array}$ & $\begin{array}{l}-0.010 \\
(-1.325)\end{array}$ & $\begin{array}{l}0.000 \\
(0.236)\end{array}$ & $\begin{array}{l}-0.038 \\
(-0.724)\end{array}$ & $\begin{array}{c}0.030 \\
(1.199)\end{array}$ \\
\hline Imp. lag in trading days & $\begin{array}{l}-0.000 \\
(-0.126)\end{array}$ & $\begin{array}{l}-0.000 \\
(-0.138)\end{array}$ & $\begin{array}{l}-0.000 \\
(-0.099)\end{array}$ & $\begin{array}{l}0.000 \\
(0.469)\end{array}$ \\
\hline Death lag in trading days & $\begin{array}{l}-0.000 \\
(-0.406)\end{array}$ & $\begin{array}{l}0.000 \\
(0.280)\end{array}$ & $\begin{array}{l}-0.000 \\
(-0.704)\end{array}$ & $\begin{array}{l}-0.000 \\
(-1.167)\end{array}$ \\
\hline $\begin{array}{l}\text { Average proportion of total } \\
\text { justification categories }\end{array}$ & $\begin{array}{c}-0.007 \\
(-1.033)\end{array}$ & $\begin{array}{l}-0.001 \\
(-0.544)\end{array}$ & $\begin{array}{l}-0.041 \\
(-0.877)\end{array}$ & $\begin{array}{l}-0.010 \\
(-0.429)\end{array}$ \\
\hline
\end{tabular}

***, **, * indicate significance at the $0.01,0.05$ and 0.10 level respectively. 
Table 6

\section{MAIN2AIM cross sectional Model II coefficients and $\mathbf{t}$ - statistics}

Cross sectional model II in which dependent variables are the following model I coefficients: intercept; intercept dummy variable representing the post implementation abnormal return; the announcement day abnormal return; and the implementation day abnormal return, that were estimated for each firm in the sample. Abbreviations are: announcement (Ann.), implementation (Imp.), abnormal (Ab.), $t$ - statistics are in parenthesis. The variable "Amount of justification provided for switch" refers to the number of justification categories used by each firm divided by the number of justification categories identified in table 1 .

\begin{tabular}{|c|c|c|c|c|}
\hline \multirow[b]{2}{*}{ Independent Variables } & \multicolumn{4}{|c|}{ Model II Dependent Variables } \\
\hline & $\begin{array}{l}\text { Model I } \\
\text { Intercept }\end{array}$ & $\begin{array}{l}\text { Model I } \\
\text { Intercept } \\
\text { dummy }\end{array}$ & $\begin{array}{l}\text { Model I } \\
\text { Ann. day } \\
\text { Ab. return }\end{array}$ & $\begin{array}{l}\text { Model I Imp. } \\
\text { day Ab. } \\
\text { return }\end{array}$ \\
\hline Intercept & $\begin{array}{l}-0.012 \\
(-1.254)\end{array}$ & $\begin{array}{l}-0.000 \\
(-0.170)\end{array}$ & $\begin{array}{l}-0.042 \\
(-0.747)\end{array}$ & $\begin{array}{c}0.044 \\
(0.873)\end{array}$ \\
\hline Model I intercept coefficient & & $\begin{array}{l}-0.007 \\
(-0.448)\end{array}$ & $\begin{array}{c}0.085 \\
(0.217)\end{array}$ & $\begin{array}{c}0.251 \\
(0.723)\end{array}$ \\
\hline Model I intercept dummy & $\begin{array}{c}-0.113 \\
(-0.448)\end{array}$ & & $\begin{array}{l}-1.918 \\
(-1.231)\end{array}$ & $\begin{array}{l}1.450 \\
(1.052)\end{array}$ \\
\hline Model I Ann. day Ab. return & $\begin{array}{c}0.002 \\
(0.217)\end{array}$ & $\begin{array}{l}-0.003 \\
(-1.231)\end{array}$ & & $\begin{array}{l}-0.030 \\
(-0.533)\end{array}$ \\
\hline Model I Imp. day Ab. return & $\begin{array}{c}0.008 \\
(0.723)\end{array}$ & $\begin{array}{c}0.003 \\
(1.052)\end{array}$ & $\begin{array}{l}-0.038 \\
(-0.533)\end{array}$ & \\
\hline Model I market coefficient & $\begin{array}{c}0.000 \\
(0.043)\end{array}$ & $\begin{array}{c}0.002 \\
(1.223)\end{array}$ & $\begin{array}{c}0.039 \\
(0.886)\end{array}$ & $\begin{array}{l}-0.021 \\
(-0.544)\end{array}$ \\
\hline $\begin{array}{l}\text { Model I market interaction } \\
\text { coefficient }\end{array}$ & $\begin{array}{c}0.003 \\
(0.614)\end{array}$ & $\begin{array}{c}0.002 \\
(1.661)^{*}\end{array}$ & $\begin{array}{c}0.036 \\
(1.287)\end{array}$ & $\begin{array}{l}-0.010 \\
(-0.401)\end{array}$ \\
\hline Model I SMB coefficient & $\begin{array}{c}-0.003 \\
(-0.491)\end{array}$ & $\begin{array}{l}-0.000 \\
(-0.263)\end{array}$ & $\begin{array}{c}-0.072 \\
(-1.685)^{*}\end{array}$ & $\begin{array}{c}0.029 \\
(0.778)\end{array}$ \\
\hline Model I VMG coefficient & $\begin{array}{l}-0.001 \\
(-0.346)\end{array}$ & $\begin{array}{c}0.000 \\
(0.577)\end{array}$ & $\begin{array}{c}0.028 \\
(1.329)\end{array}$ & $\begin{array}{c}0.044 \\
(2.389)^{* *}\end{array}$ \\
\hline $\begin{array}{l}\text { Market value percentile rank on } \\
\text { Imp. day }\end{array}$ & $\begin{array}{c}0.004 \\
(0.607)\end{array}$ & $\begin{array}{l}-0.001 \\
(-0.991)\end{array}$ & $\begin{array}{c}0.059 \\
(1.645)\end{array}$ & $\begin{array}{c}0.026 \\
(0.806)\end{array}$ \\
\hline $\begin{array}{l}\text { Bid ask spread average } \\
\text { percentage, } \mathrm{t}-255 \text { through } \mathrm{t}-6\end{array}$ & $\begin{array}{c}0.014 \\
(0.507)\end{array}$ & $\begin{array}{c}-0.021 \\
(-3.103)^{* *}\end{array}$ & $\begin{array}{c}0.016 \\
(0.095)\end{array}$ & $\begin{array}{l}-0.015 \\
(-0.102)\end{array}$ \\
\hline $\begin{array}{l}\text { Standardised volume, } \mathrm{t}-255 \\
\text { through } \mathrm{t}-6\end{array}$ & $\begin{array}{c}0.006 \\
(1.895)^{*}\end{array}$ & $\begin{array}{c}0.001 \\
(1.369)\end{array}$ & $\begin{array}{c}0.012 \\
(0.597)\end{array}$ & $\begin{array}{c}-0.022 \\
(-1.220)\end{array}$ \\
\hline $\begin{array}{l}\text { NPD proportion day, } \mathrm{t}-255 \\
\text { through } \mathrm{t}-6\end{array}$ & $\begin{array}{c}0.009 \\
(1.266)\end{array}$ & $\begin{array}{c}0.000 \\
(0.032)\end{array}$ & $\begin{array}{c}0.053 \\
(1.175)\end{array}$ & $\begin{array}{l}0.008 \\
(0.193)\end{array}$ \\
\hline $\begin{array}{l}\text { Average free float, } \mathrm{t}-255 \\
\text { through } \mathrm{t}-6\end{array}$ & $\begin{array}{c}-0.002 \\
(-0.270)\end{array}$ & $\begin{array}{c}0.003 \\
(1.767)^{*}\end{array}$ & $\begin{array}{l}-0.024 \\
(-0.596)\end{array}$ & $\begin{array}{c}-0.062 \\
(-1.746)^{*}\end{array}$ \\
\hline Imp. lag in trading days & $\begin{array}{l}-0.000 \\
(-0.080)\end{array}$ & $\begin{array}{c}0.000 \\
(1.267)\end{array}$ & $\begin{array}{l}-0.000 \\
(-0.562)\end{array}$ & $\begin{array}{l}-0.000 \\
(-0.952)\end{array}$ \\
\hline Death lag in trading days & $\begin{array}{c}0.000 \\
(0.248)\end{array}$ & $\begin{array}{l}-0.000 \\
(-0.507)\end{array}$ & $\begin{array}{l}-0.000 \\
(-1.429)\end{array}$ & $\begin{array}{l}-0.000 \\
(-0.735)\end{array}$ \\
\hline $\begin{array}{l}\text { Average proportion of total } \\
\text { justification categories }\end{array}$ & $\begin{array}{c}0.026 \\
(1.685)^{*}\end{array}$ & $\begin{array}{l}-0.005 \\
(-1.181)\end{array}$ & $\begin{array}{c}0.085 \\
(0.904)\end{array}$ & $\begin{array}{c}0.035 \\
(0.426)\end{array}$ \\
\hline Shareholder protection statement & $\begin{array}{l}-0.004 \\
(-0.885)\end{array}$ & $\begin{array}{c}0.002 \\
(1.334)\end{array}$ & $\begin{array}{c}-0.025 \\
(-0.908)\end{array}$ & $\begin{array}{c}0.001 \\
(0.035)\end{array}$ \\
\hline
\end{tabular}

$* * *, * *, *$ indicate significance at the $0.01,0.05$ and 0.10 level respectively. 


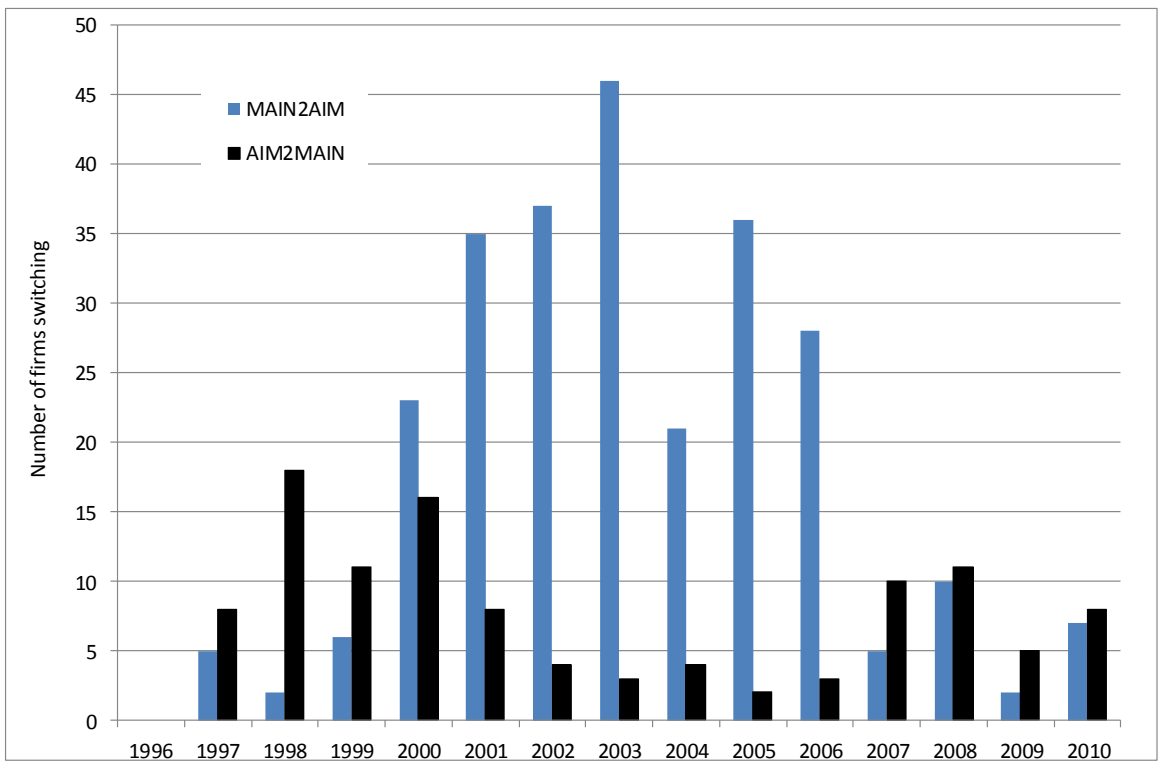

Figure 1

Number of firms moving from AIM2MAIN and MAIN2AIM in each year of the study period

AIM2MAIN firms are those that transfer from the AIM to the main market. MAIN2AIM firms are those transferring in the opposite direction. London Stock Exchange New Issues and IPO Summary (LSE 2011b). 
Panel A: AIM2MAIN sample

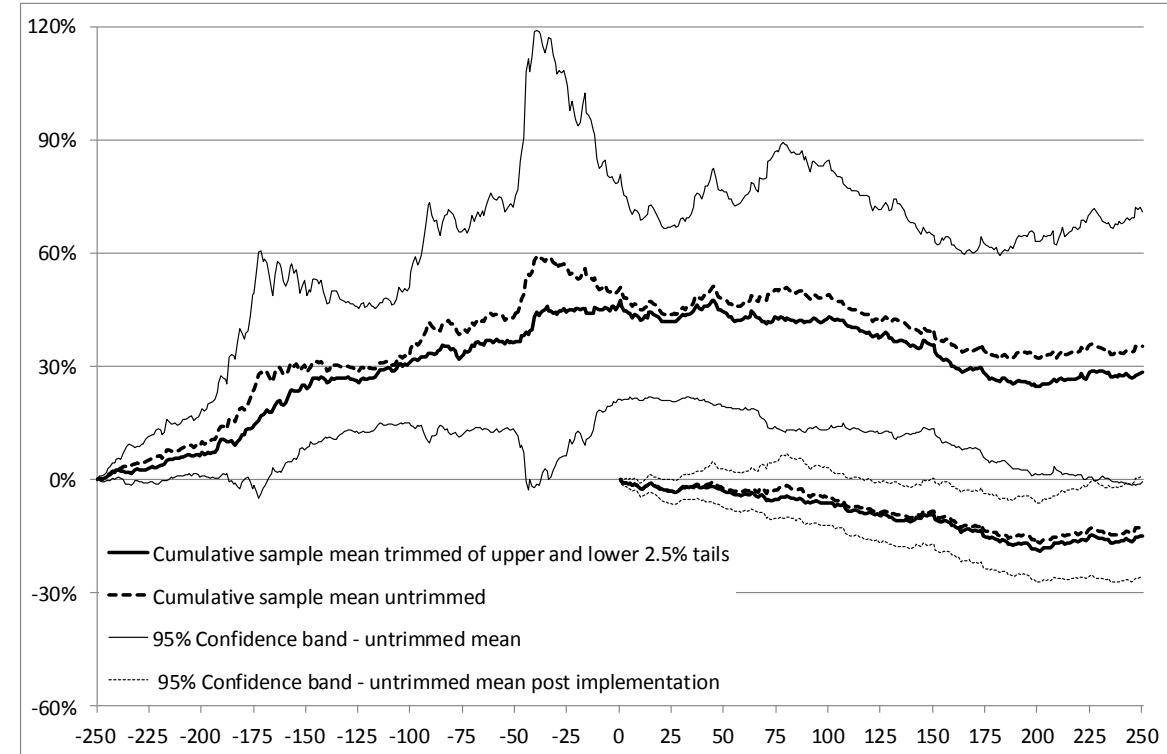

Panel B: MAIN2AIM sample

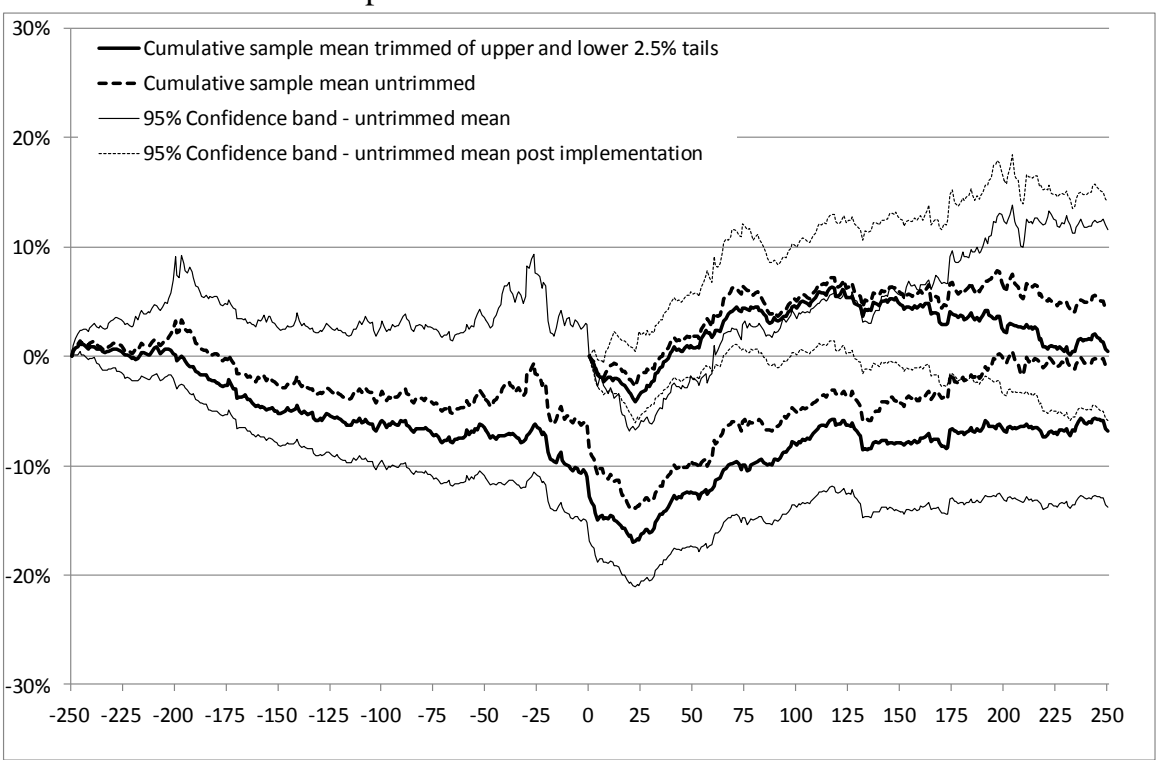

Figure 2

\section{Buy and hold excess returns relative to the market benchmark portfolio}

Aggregate buy and hold returns cumulated over the whole 501 day event period and from the implementation date of portfolios that are equally weighted at the start of respective periods but not re-balanced thereafter. Market adjustment is by daily geometric differencing between firm excess returns and benchmark excess returns. 
Panel A: Trimmed upper and lower $2.5 \%$ tails removed each day

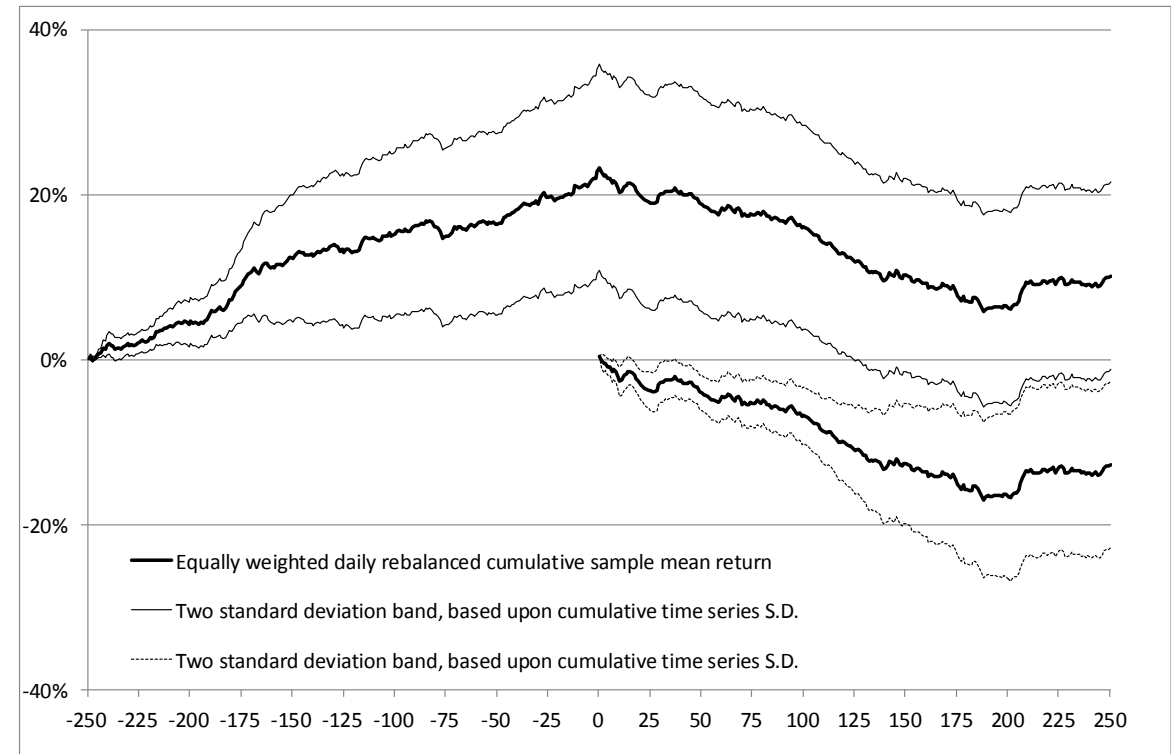

Panel B: Untrimmed sample

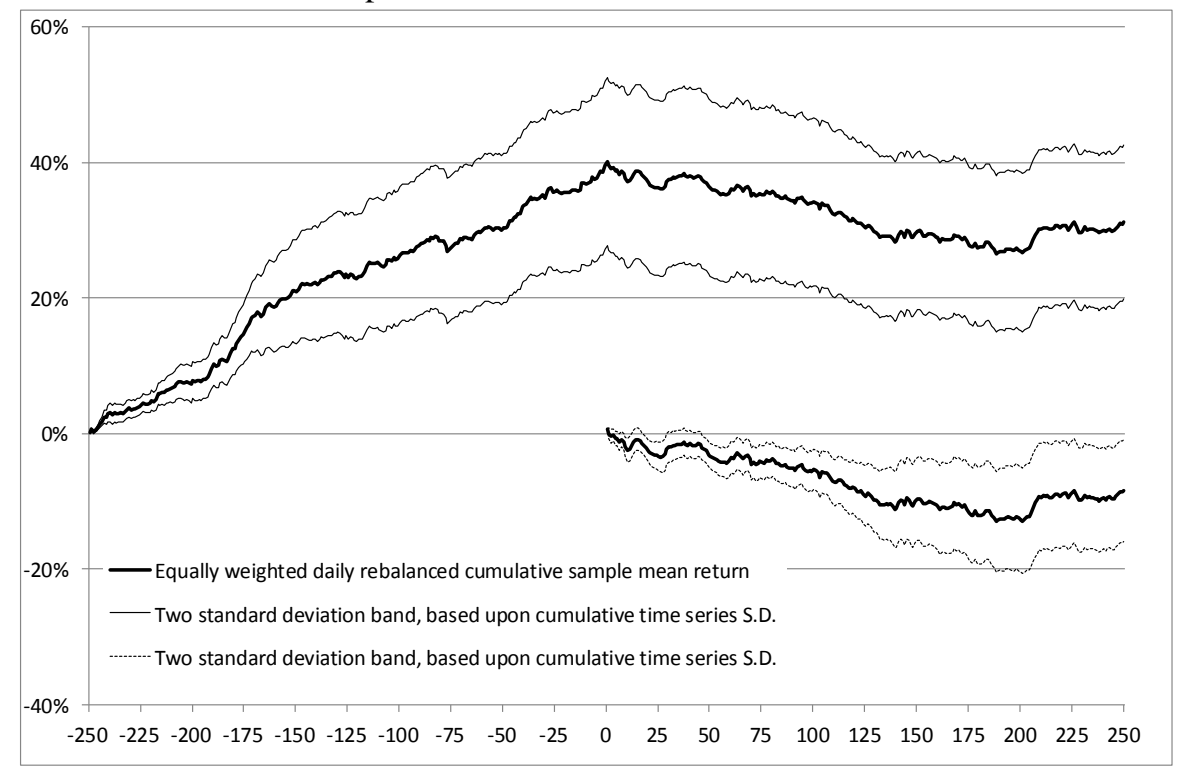

Figure 3

Cumulative daily-rebalanced equally weighted average returns AIM2MAIN

The daily rebalanced equally weighted sample mean returns of the 110 AIM2MAIN firms are cumulated over the whole 501 day event window and from the implementation date. 
Panel A: Trimmed upper and lower $2.5 \%$ tails removed each day

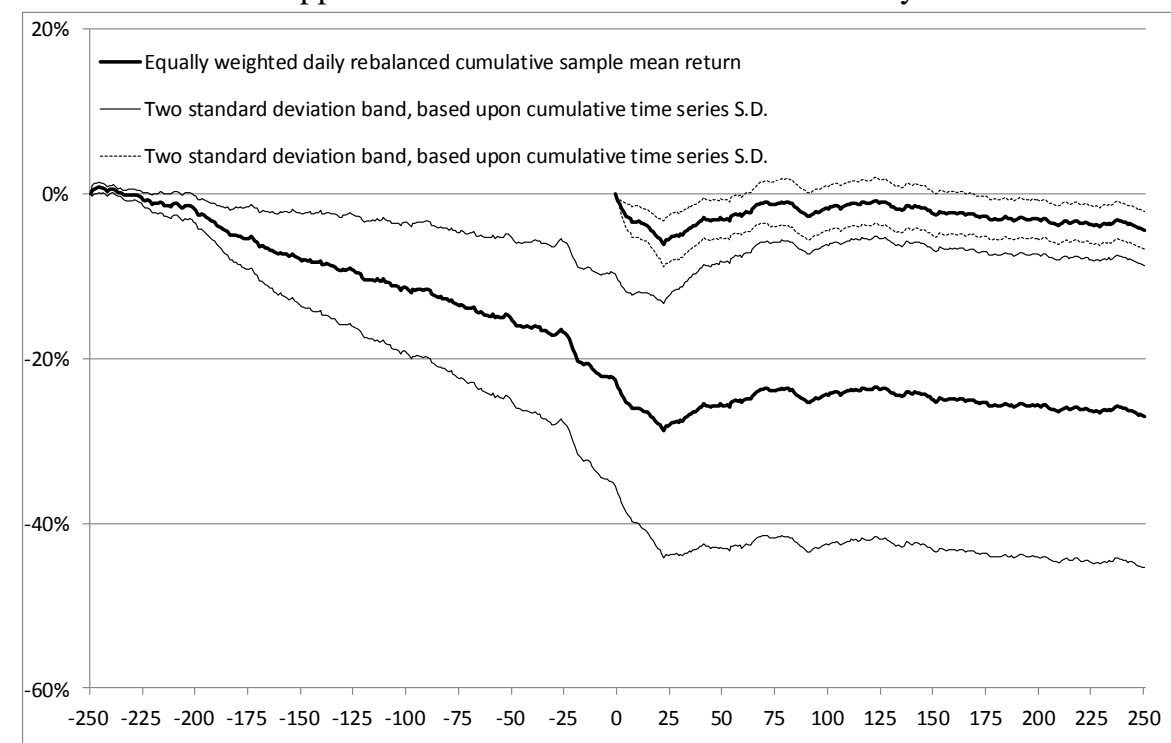

Panel B: Untrimmed sample

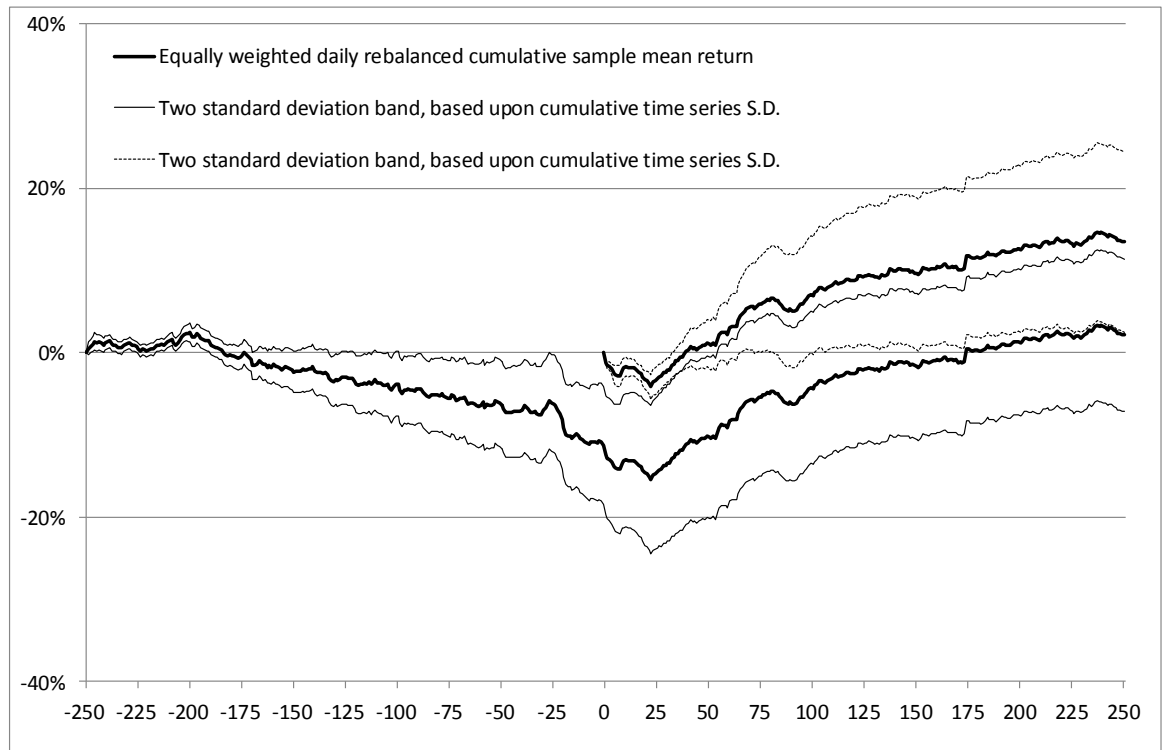

Figure 4

Cumulative daily-rebalanced equally weighted average returns MAIN2AIM

The daily rebalanced equally weighted sample mean returns of the 261 MAIN2AIM firms are cumulated over the whole 501 day event window and from the implementation date. 


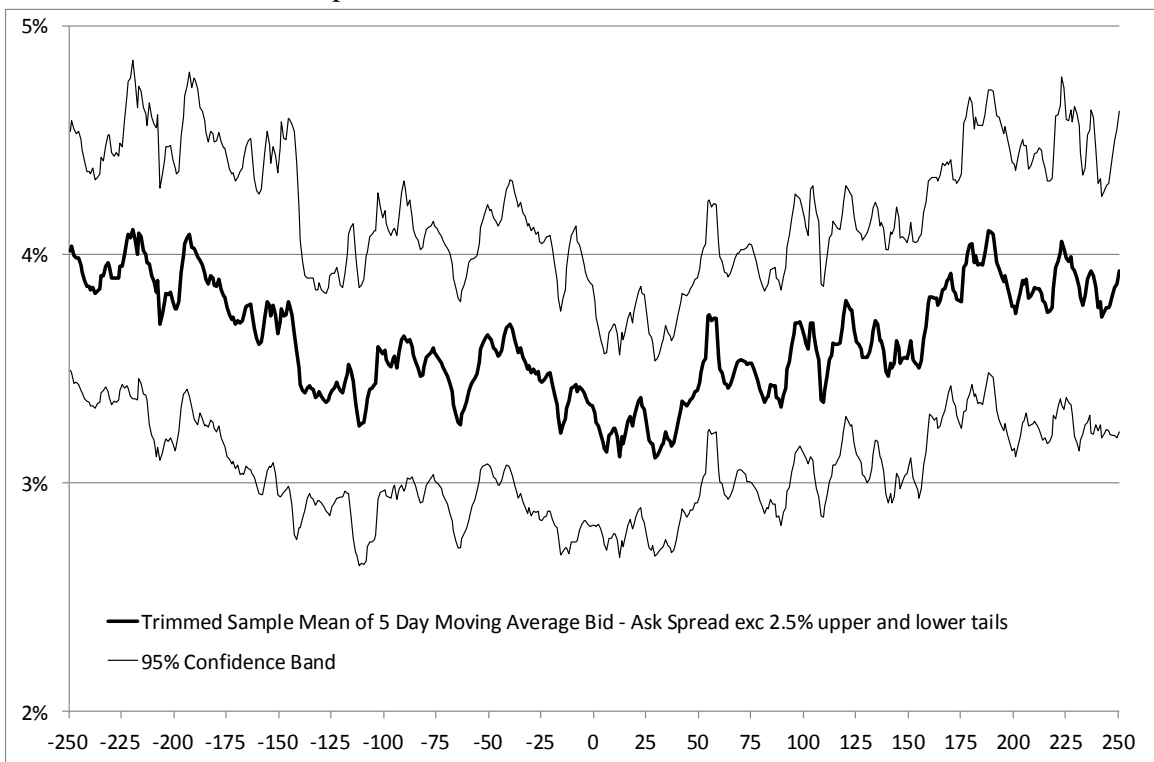

Panel B: MAIN2AIM sample

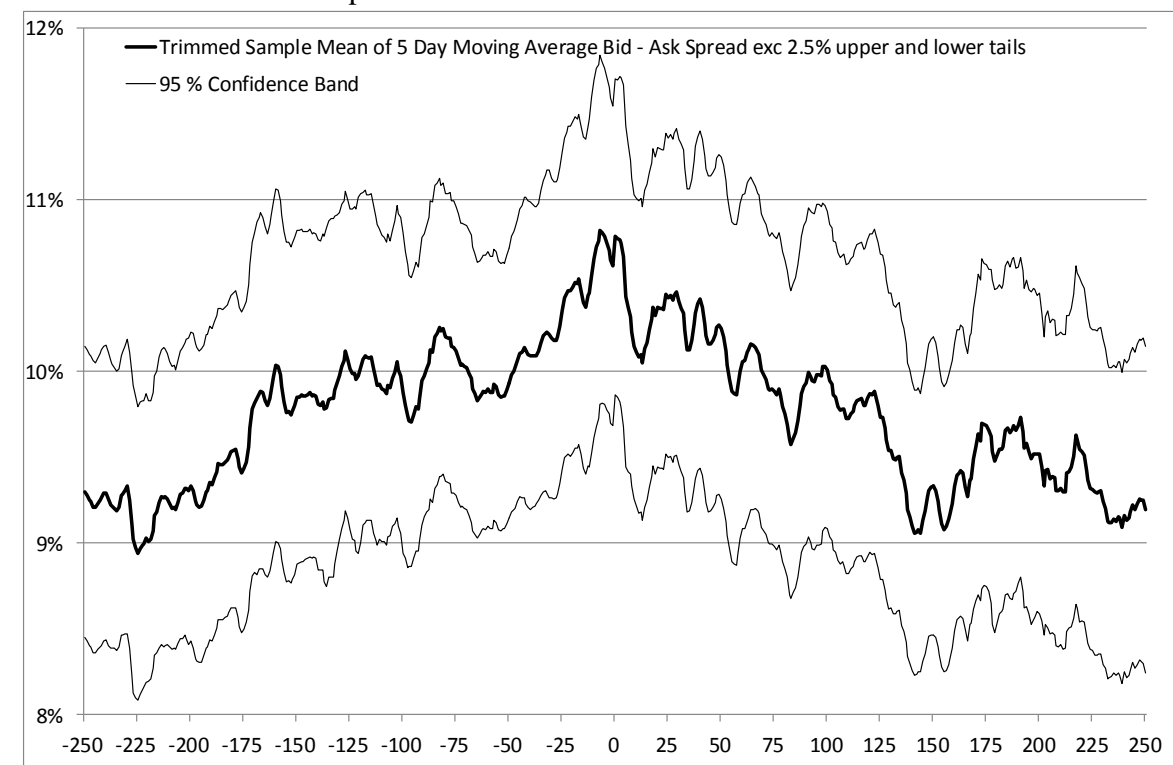

Figure 5

Time series of sample mean bid ask spread and $95 \%$ confidence intervals.

The horizontal axis is event time in trading days, the vertical axis is the daily trimmed cross sectional sample mean of individual firms' rolling five day moving average logarithmic percentage bid ask spread. Trimming excludes the daily upper and lower $2.5 \%$ tails. 
Panel A: AIM2MAIN sample

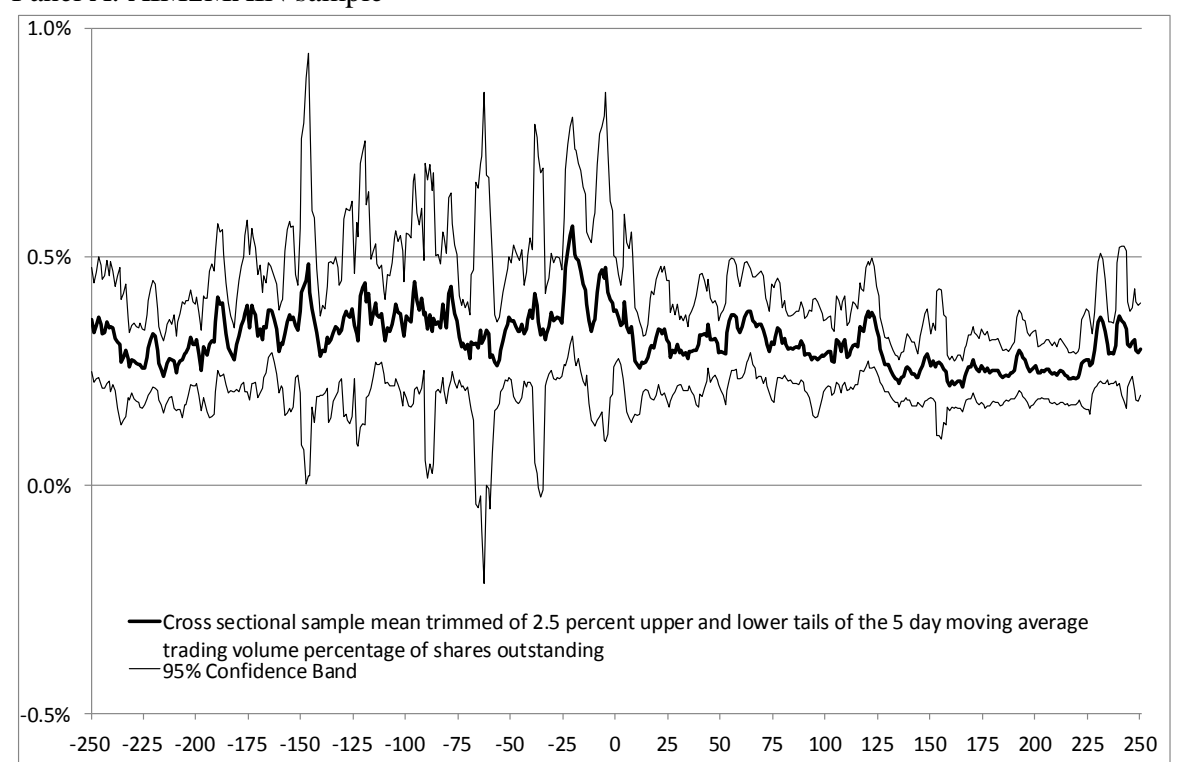

Panel B: MAIN2AIM sample

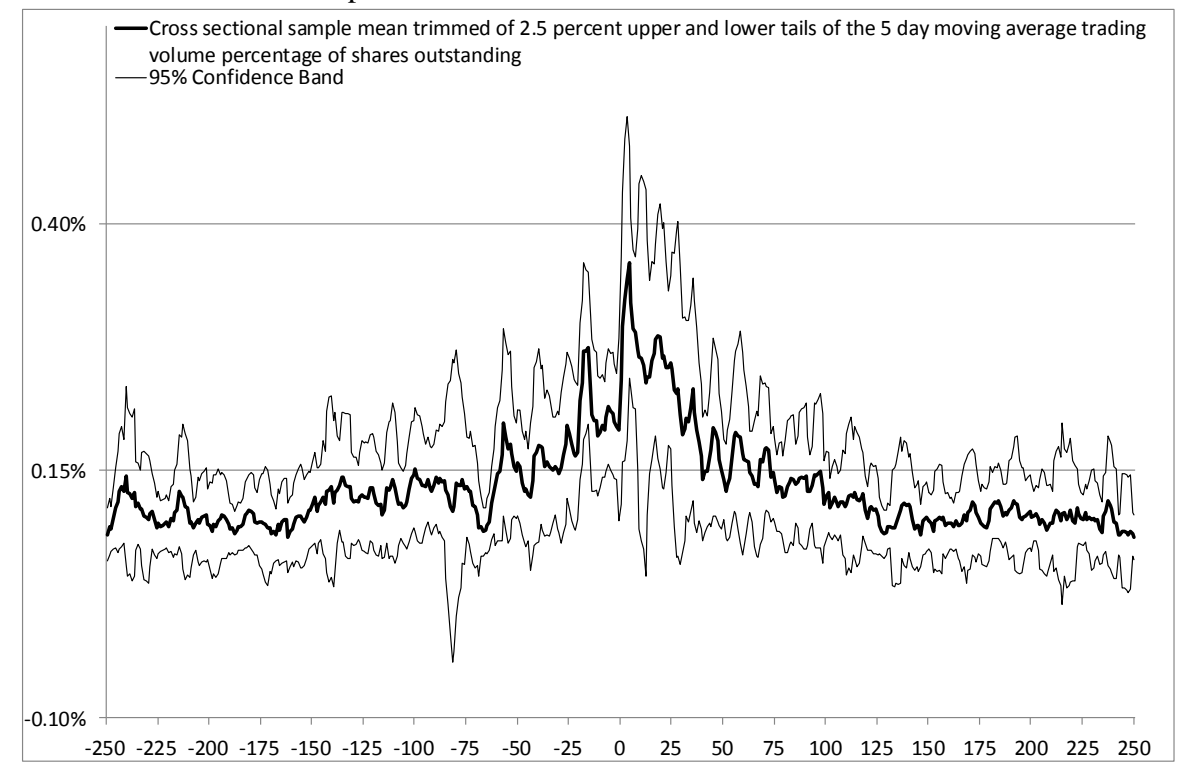

Figure 6

Sample mean of daily trading volume and $95 \%$ confidence intervals

Sample mean trimmed of the upper and lower $2.5 \%$ tails of the 5 day moving average trading volume as a percentage of shares outstanding. 
Panel A: AIM2MAIN sample

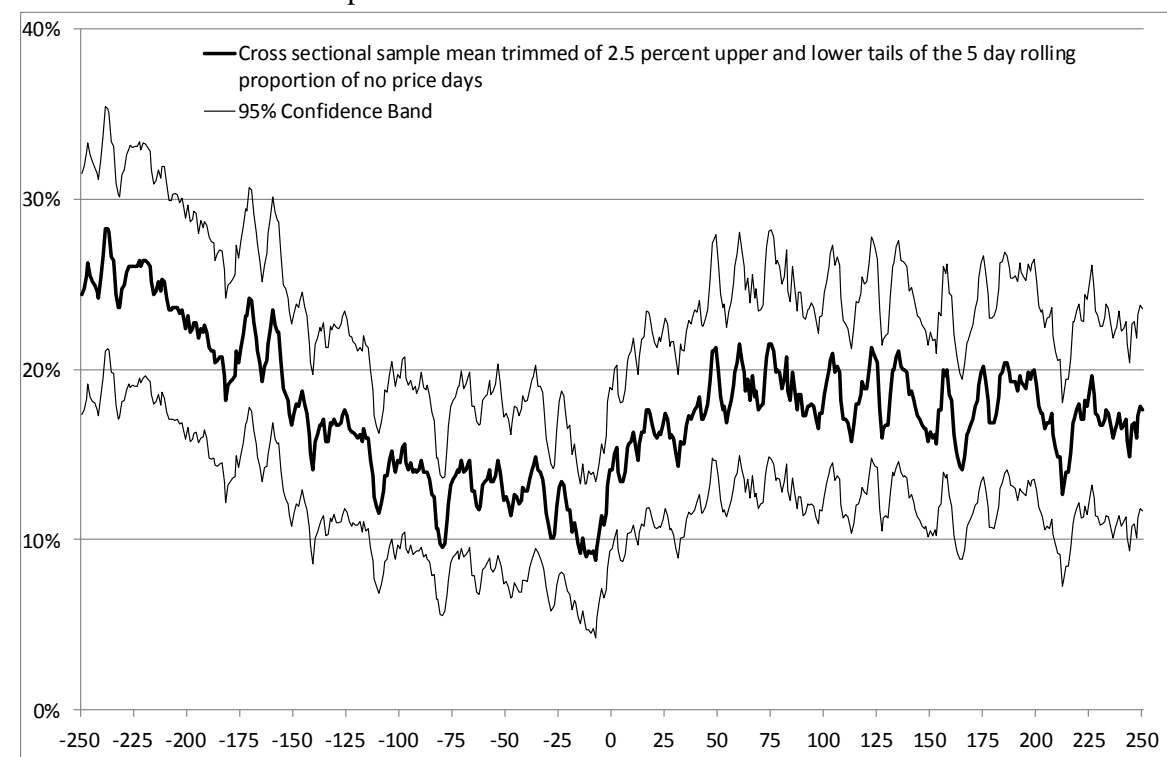

Panel B: MAIN2AIM sample

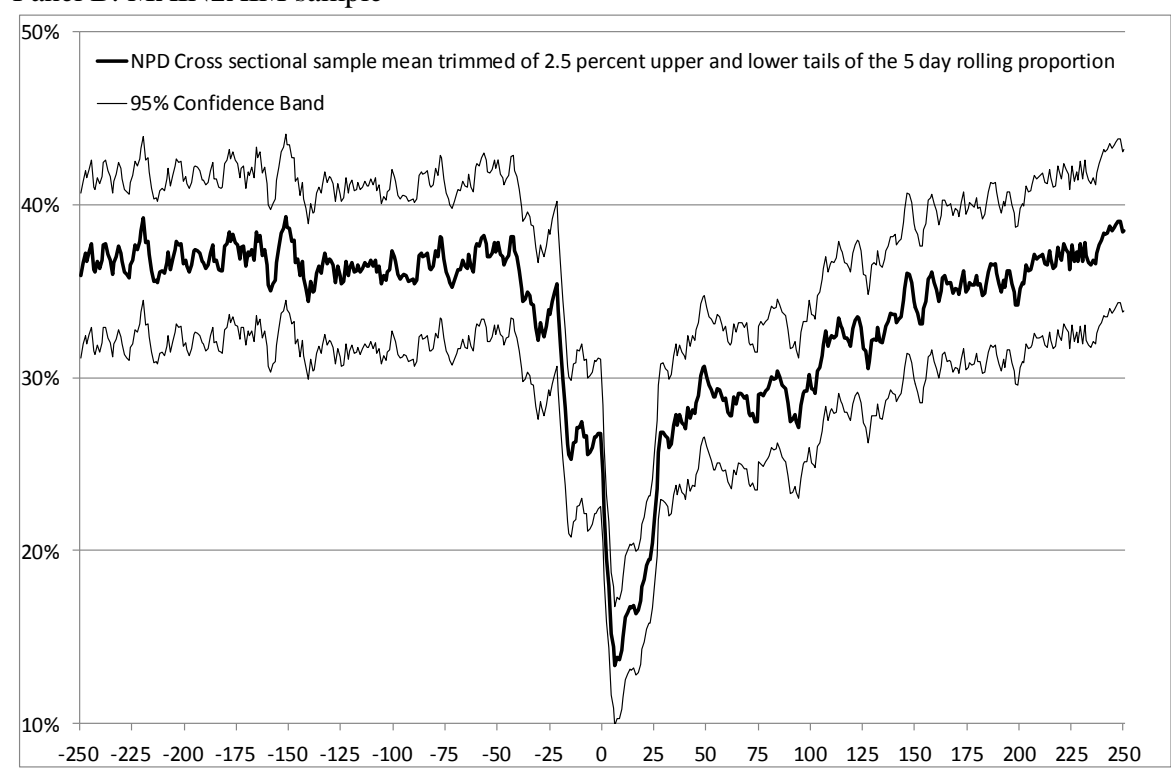

Figure 7

Sample mean and confidence intervals for the proportion of no price days

A rolling proportion of the previous 5 days in which no trades and no price changes are recorded is calculated for each firm (NPD). Time series of the cross sectional means of the rolling five day NPD with the upper and lower $2.5 \%$ tails trimmed are plotted complete with $95 \%$ confidence intervals calculated using the untrimmed data. 